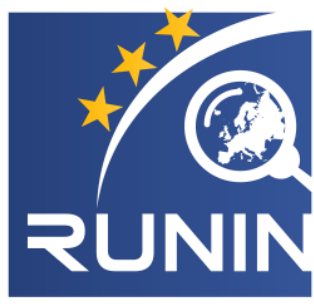

The Role of Universities in Innovation and Regional Development

\title{
Assessing the Impact of University-Firm Collaboration on Innovation-related Financial Performance
}

WORKING PAPER \# 02/2020

DOI: https://doi.org/10.3990/4.2535-5686.2020.02

Available at https://runinproject.eu/results/working-paper-series/

\section{Sergio Manrique *}

Researcher / PhD Fellow

Department of Business - Universitat Autònoma de Barcelona (ES)

$\bowtie$ sergioandres.manrique@uab.cat

@sergioman90

* Corresponding Author

\section{Emili Grifell-Tatjé}

Professor of Management and Business Economics

Department of Business - Universitat Autònoma de Barcelona (ES)

$\bowtie$ emili.grifell@uab.cat 


\title{
Assessing the Impact of University-Firm Collaboration on Innovation-related Financial Performance
}

\begin{abstract}
Collaboration between universities and firms has boosted worldwide, due to the transition towards open business models on the industry side and the development of universities' third mission on the academia side. Such collaboration is expected to contribute positively to the improvement and development of products and practices at firms, which should lead to better corporate financial performance. We argue that these financial benefits should be the major motivation form firms to 'open' their R\&D activities and interact with universities. Despite there is a broad literature on the determinants of university-firm collaboration (UFC) and its effects on R\&D and innovation processes at firms, the study of its impact on corporate financial performance, especially in empirical terms, remains unexplored. This paper attempts to assess the impact of UFC on the corporate financial performance related to firm innovation efforts. To do so, we isolate the innovation-related inputs used by firms to produce radically and incrementally innovative products, and compare the innovationrelated profitability of collaborating and non-collaborating firms with a benchmarking model based on Empirical Index Numbers (EINs) and Data Envelopment Analysis (DEA) efficiency measures for a sample of 1,060 observations from the chemicals industry in Spain for the period 2005-2015. Our findings show that firms that collaborate with universities have, in average, more intensive innovation efforts, evidenced in significantly higher costs of R\&D labour and capital. Collaborating firms also perform higher sales of incrementally and radically innovative products, generating higher innovation-related profitability in the observed period. The profitability gain of collaborating firms over non-collaborating firms is given mainly by changes in technical efficiency and partly by a technology gap, while it is not supported by changes in firm size/scale and price recovery. Through this paper, we contribute to the understanding of the impact of UFC on firm performance in economic terms.
\end{abstract}

Keywords: University-Firm Collaboration (UFC); Firm Performance; Profitability; Innovation; Empirical Index Numbers (EINs); Benchmarking; Data Envelopment Analysis (DEA).

JEL: C43; D24; I23; L25; M21; O30; R15.

This working paper was presented at the $5^{\text {th }}$ Geography of Innovation Conference, held in Stavanger, Norway on January $29^{\text {th }}-31^{5 t}, 2020$, organised by University of Stavanger in partnership with RUNIN Project. 


\section{Assessing the Impact of University-Firm Collaboration on Innovation-related Financial Performance}

\section{Content}

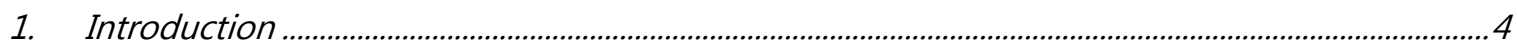

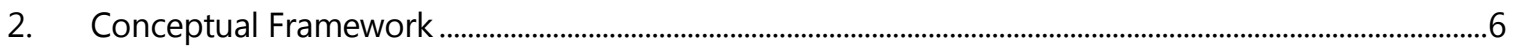

3. Methodology ..................................................................................................................................................

3.1. Decomposing Innovation-related Profitability Gain ........................................................... 12

3.2. Testing and Benchmarking the Gaps.................................................................................. 19

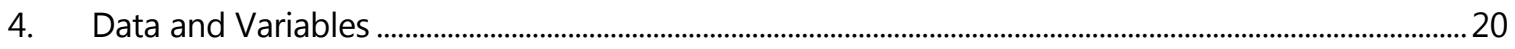

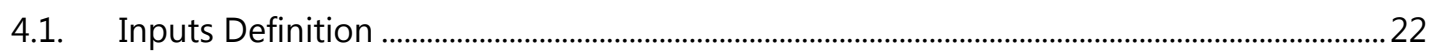

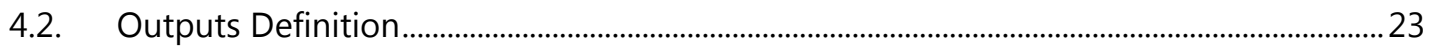

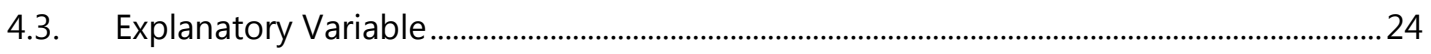

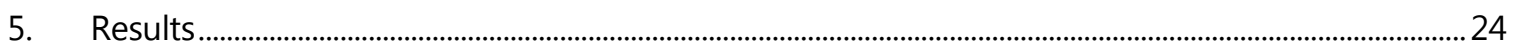

6. Discussion and Conclusions ..............................................................................................................................

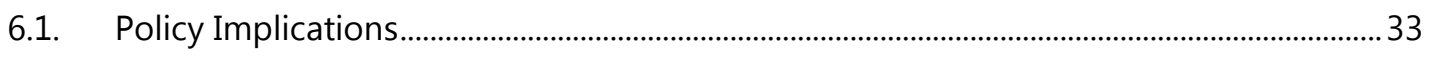

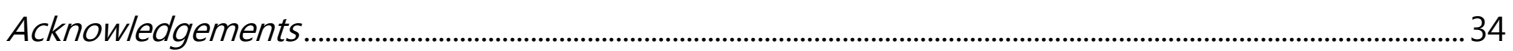

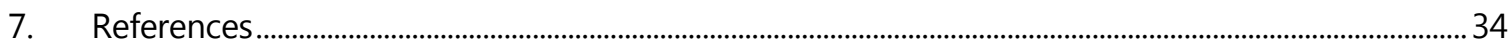

\section{Tables and Figures}

Figure 1 - Grifell-Tatjé \& Lovell's (2015) Proposal for Profititability Change Analysis..........................13

Figure 2 - Representation of Technical Efficiency Gap ............................................................................... 17

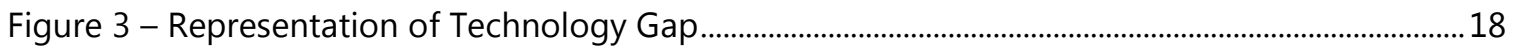

Figure 4 - Representation of Size-Scale Effect...................................................................................... 18

Figure 5 - Measures of Reference for Benchmarkingbased on Grifell-Tatjé \& Lovell (2015)............. 19

Figure 6 - Number of Observations per Year and Group .......................................................................21

Figure 7 - Profitability of Non-Collaborating and Collaborating Firms per year (2005-2015) ..........26

Table 1 - Revenues, Costs and Profitability Change with Empirical Index Numbers .............................. 14

Table 2 - Summary of Averages for the Variables of Interests ......................................................................24

Table 3 - t-test for Profitability Mean Difference ........................................................................................26

Table 4 - Benchmarking Scenario 1: Collaborating Average vs Non-collaborating Average ............27

Table 5 - Benchmarking Scenario 2: Collaborating Profitable vs Non-collaborating Profitable....... 28

Table 6 - Benchmarking Scenario 3: Collaborating Profitable vs Non-collaborating Average..........29

Table 7 - Benchmarking Scenario 4: Collaborating Average vs Non-collaborating Profitable........... 30

Table 8 - Summary of Benchmarking Results ............................................................................................... 32 


\section{Assessing the Impact of University-Firm Collaboration on Innovation-related Financial Performance}

\section{Introduction}

The transition towards open business models on the industry side (Chesbrough, 2006, Laursen \& Salter, 2006), evidenced by a greater openness and flexibility of R\&D and innovation activities at firms, and the development of universities' third mission on the academia side (Göransson \& Brundenius, 2011), evidenced by a new role assumed by universities beyond research and education with respect to regional engagement and innovation, has generated a boost of university-firm collaboration (hereafter referred as UFC) and other R\&D interactions worldwide, with expected benefits for both universities and firms, as well as for the surrounding region(s) where such interactions take place. Despite there has been relevant research on the theme of UFC (Perkmann \& Walsh, 2007; Perkmann et al., 2013; Mascarenhas, Ferreira, \& Marques, 2018), there is a lack of research focusing on how this phenomenon affects firm performance, especially in financial terms, which must be considered one of the main incentives for firms to interact with external players such as universities. Therefore, this working paper is aimed at assessing the expected financial benefits for firms from collaboration with university using a novel methodological approach, based on a benchmarking exercise for firms of the Chemicals industry in Spain.

From a neoclassical view of business economics and in line with the traditional position of the lobbying group The Business Roundtable ${ }^{1}$ (BRT), corporations would be interested in engaging in UFC, among other R\&D collaborations, chiefly if it contributes to serving shareholders' interests through the generation of profits, as stated at well-known Milton Friedman 1970's essay "The Social Responsibility of Business Is to Increase Its Profits". Openness in R\&D and innovation activities generally, and UFC specifically, should be primarily justified and motivated by financial means. In this sense, we argue that through collaboration with university, firms can gain access to fundamental knowledge and the possibility of conducting high quality research, essential for innovation, as well as training, consultancy and technical support. Accordingly, UFC is expected to create economic value for firms via technical change, by enhancing their absorptive capacity (Cohen \& Levinthal, 1990) and innovative performance (Laursen \& Salter, 2006), evidenced in the development of new and/or improved products and practices at corporate level; such innovation can help firms to improve their financial performance and survive in a global and competitive market, supporting BRT's and Friedman's neoclassical view.

\footnotetext{
${ }^{1}$ The Business Roundtable is an association of chief executive officers of America's leading companies. Visit https://www.businessroundtable.org for more information. The predominance of shareholders' interests in the stated purpose of corporations was maintained by BRT in its periodical issues between 1997 and 2019.
} 


\section{Assessing the Impact of University-Firm Collaboration on Innovation-related Financial Performance}

Primarily, we look forward to answering a broad research question: ' What is the impact of collaboration with university on firm financial performance? And in order to answer this research question, three specific research questions have been formulated:

1) How can firm innovation-related financial performance be measured?

2) Do collaborating and non-collaborating firms have significant differences in terms of innovation-related financial performance?

3) How does UFC help to create economic value at firms? Does it improve technology and managerial efficiency? And what is the profitability gain associated to such improvements?

We provide empirical evidence to answer these questions based on a sample of firms from the Chemicals industry in Spain in the decade between 2005 and 2015. For the first question, we propose and implement the concept of innovation-related profitability which considers the R\&D inputs used by firms to produce innovative products. Afterwards, we tackle the second question by statistically analysing the differences in the computed profitability between collaborating and non-collaborating firms. Finally, the third question is approached by using an empirical index numbers (EINs) approach to profitability gain based on Grifell-Tatjé \& Lovell (2015); this profitability gain is estimated using the economic concept of distance functions (Shephard, 1970), computed through non-parametric programming techniques known as Data Envelopment Analysis (DEA) (Charnes, Cooper \& Rhodes, 1978). We implement a benchmarking model based on the decomposition of the innovationrelated profitability gain of collaborating over non-collaborating firm, which helps to understand how UFC affects firm performance in economic terms.

In brief, we have found that firms that collaborate with university perform, in average, higher sales of both incrementally and radically innovative products. However, collaborating firms also show significantly higher efforts in terms of innovation-related capital and personnel investments. We also find that collaborating firms are larger in average using the total sales as size proxy. Finally, our provisional results suggest that collaborating firms have, in average, higher innovation-related profitability during the studied period. We analyse the existent profitability gain of collaborating firms over non-collaborating firm by decomposing it in: 1 ) the gap in productivity between collaborating and non-collaborating firms given by differences in technical efficiency and technology between the two groups, 2) changes in the size and scale of operations of firms in relation to the interaction with university, and 3) the gap in price recovery between the two groups. In the end, our empirical findings suggest that collaboration with university has a positive effect on the innovation-related financial performance of firms, based on evidence from the chemicals industry in Spain. With this work, we 


\section{Assessing the Impact of University-Firm Collaboration on Innovation-related Financial Performance}

contribute to understanding the impact of collaboration with university on firms in economic terms via innovation.

This paper is structured as follows: The next section (2) reviews the relevant past literature on the theme of university-firm collaboration and develops the concept of innovation-related profitability. Afterwards, (3) the methodology of this work, based on empirical index numbers, is explained, and (4) the research design is described. Finally, (5) the results from the statistical analysis as well as from the benchmarking model are presented, and (6) conclusions and final policy implications are discussed.

\section{Conceptual Framework}

This work revolves around the concepts of university-firm collaboration (UFC) and innovation-related profitability. In this section, we develop a conceptual framework based on a literature review of the motivations, types and expected impacts of collaboration with university on firms, discussing how these UFC drivers relate to value creation and profitability at firms. Additionally, the concept of innovation-related profitability is introduced. Past literature has dedicated great efforts to analysing the determinants of UFC, among other R\&D and innovation collaborations, from both industry and academia perspectives, as well as to -albeit to a more limited extentstudying the effect of such collaboration on firm innovation outcomes (e.g. revenues associated with incremental/radical innovation, number of patents). However, further steps towards understanding the impact of UFC on firm financial performance, especially in empirical terms, are still missing.

From the perspective of universities -and higher education and research institutions, in general-, collaboration with firms has become a tool to enhance their contribution to the innovation and development of regions with regards to the role that universities play in economic growth, technology development and labour market dynamics, among other socioeconomic processes, constituting universities' third mission (Göransson \& Brundenius, 2011). University-firm collaboration (UFC), also denominated as university-industry or university-business interaction in many studies, has also gained notorious interest in academia as a way to promote and strengthen non-academic and entrepreneurial activities carried out by researchers and academics at higher education and research institutions (Abreu \& Grinevich, 2013; D'Este \& Patel, 2007) and academic engagement in knowledge exchange (Hughes \& Kitson, 2012). 


\section{Assessing the Impact of University-Firm Collaboration on Innovation-related Financial Performance}

Thus, UFC can serve internationalisation and excellence goals at universities ${ }^{2}$. However, this paper focuses on the corporate perspective, and we are therefore interested in deepening on the possible motivations, types and impacts of UFC at firms.

As per Friedman's neoclassical approach (1970), the primary goal of any business is to maximize the value of its shareholders or owners through its business activity, by producing and/or selling goods or services to customers in a profitable way. However, firms can also have other objectives and duties, as they interact at and are part of a social, economic and political context, given the location of their facilities and the markets they serve; it implies dealing with the needs and interests of different stakeholders, both internal (e.g., employees and owners) and external (e.g., suppliers, customers and communities) -stakeholder approach- (Freeman, 1984). The motivations to engage in UFC can be explained from both perspectives. However, and bearing in mind that the stakeholder approach has already been widely approached in the past (see literature on e.g. Triple/Quadruple Helix of Innovation and National/Regional Innovation Systems), in this paper we follow the neoclassical view as we are interested in studying the impact of UFC on the financial performance of firms, that is, how such collaboration contributes to the generation of economic value for firm shareholders. Despite we do not mean to ignore the impacts that UFC might have on regions and stakeholders others than shareholders, and when it comes to the side of firms in this story, we decide to focus on the financial impact as the main reason that firms have for engaging in collaboration with university.

Even though the motivations to collaborate with university may vary depending on firm characteristics (e.g. size, ownership structure, age), as well as on the context (e.g., industry, geographical location, institutional context), some common incentives can be identified and discussed. Firm size, for instance, can be relevant to explain the willingness of firms to collaborate; Santoro \& Chakrabarti (2002) explain that when it comes to engaging in UFC, larger firms seek to build competences in non-core technological areas, while smaller firms focus more on problem solving in core technological areas. In both cases, university-firm collaboration is considered a tool for technology -and knowledge- transfer; nevertheless, larger firms might find easier to engage in UFC and could be more likely to receive greater financial benefits from collaborating. Firm's age and ownership structure are relevant factors when explaining the motivations for collaborating, as described by Maietta, (2015), who also finds that

\footnotetext{
${ }^{2}$ See a case study of UFC between a public university and a firm from the chemicals industry in Spain (Manrique, 2018).
} 


\section{Assessing the Impact of University-Firm Collaboration on Innovation-related Financial Performance}

cognitive and geographical proximity between universities and firms should influence positively the occurrence and implementation of UFC.

Valmaseda-Andia et al. (2015) developed a very complete review and survey on the motivations of UFC, classifying them into tactic and strategic motivations. The former includes accessing new markets, creating new companies, solving production problems, getting tax advantages and obtaining public funding, while the latter refers to anticipating technological changes, addressing complex projects and improving firm competitive position, reputation and image as potential goals motivating firms to collaborate with university. As per us, both tactic and strategic motivations are guided by the potential financial benefits that UFC can bring to the firm though innovation. Moreover, most works in past literature coincide in that having access to knowledge transfer and high quality research are relevant motivations for firms to collaborate with universities. We conclude that UFC is seen a suitable way to canalize and consolidate $R \& D$ activities at firm level in order to create economic value via innovation.

Partly based on the above motivations, different types of UFC can emerge with direct and indirect effects on firm financial performance. This taxonomy is mainly based on the activities or the mechanisms used in UFC, but could also be explained through the complexity, scope and objectives of the collaboration. One of the first attempts to develop a classification of UFC (Santoro and Chakrabarti, 2002) proposed four categories: 1) research support in the shape of financial and equipment contributions made to universities by industry, 2) cooperative research based on contract research with investigators and consultancy by faculty for addressing immediate industry problems, 3) knowledge transfer through cooperative education, curriculum development, and personnel exchanges, and 4) technology transfer via university driven research with industry expertise for addressing immediate and more specific industry issues. In any of Santoro \& Chakrabarti's categories, firms that engage in UFC should pursue financial benefits and would expect to generate profits either via research or through technological development. Later on, Abreu and Grinevich (2013) separated UFC into formal commercial activities (e.g. licensing and spin-outs), informal commercial activities (e.g. consultancy and contract research), and non-commercial activities (e.g. informal advice and public lectures).

We recognise that commercial UFC is directly and explicitly related to profitability generation though innovation at firms; nevertheless, non-commercial UFC should also be motivated by indirect benefits in firm financial performance. Soh \& Subramanian (2014) distinguished between two focuses in UFC: 1) technological recombination, 


\section{Assessing the Impact of University-Firm Collaboration on Innovation-related Financial Performance}

taking place when firms pursue internal and external innovation activities simultaneously and recombine patented technologies in developing a new innovation, and 2) scientific research, with a knowledge management view of interfirm alliances with emphasis on new publications. With a short-medium and long term perspective respectively, both technological recombination and scientific research are means for firms to create economic value via innovation. What is consistent in the literature on UFC classification is the differentiation of the activities taking place at university (research, education, others) and the firm objectives as the basis for developing a taxonomy. Furthermore, firm objectives in UFC can always be related to creation of economic value and profitability at firm-level though different means associated to innovation.

As mentioned before, firms would normally engage in collaboration with universities for getting benefits which contribute to maximizing its shareholders or owners value via innovation, in line with BRT's neoclassical view. In this sense, we would expect the impacts of UFC on firms to be either intermediate effects that lead to financial benefits or proper effects on firm finances. Openness in innovation activities (Chesbrough, 2006), expressed in the form of collaboration with university, contributes to improving the innovative performance of firms (Laursen \& Salter, 2006). Abreu and Grinevich (2013), in line with their proposed types, conclude that UFC based on commercial activities should lead to economic value generation while non-commercial activities should lead to better reputation and societal benefits, which we think also lead to economic benefits. According to Soh \& Subramanian (2014), technological recombination increases patent performance (and therefore its economic exploitation) and enhance university collaboration activities while scientific research decreases the relationship's positive effects. UFC orientation in technological development prevails over research when it comes to effects on firm performance.

Valmaseda-Andia et al.'s review synthetize UFC impacts in: 1) technical benefits (launch or improvement of products/services and production problem solving), 2) economic benefits (accessing new markets, improving sales/exports and reducing costs and risks), 3) investment benefits (increase in R\&D investments and work capital), and 4) intangible benefits (improvement of image, reputation and culture, and gains in scientific/technical knowledge and staff qualification). Despite the second and third categories explicitly refer to financial impacts, both technical and intangible benefits can also lead to economic value creation via innovation at firms. Finally, Maietta (2015) concludes that geographical proximity in UFC benefits product innovation, while university's academic production weakens it, indicating that both proximity and 


\section{Assessing the Impact of University-Firm Collaboration on Innovation-related Financial Performance}

university's focus when collaborating matter in the way UFC contributes to product innovation at firms. When considering the impacts of UFC on firm performance explicitly, most past literature has limited to either theorising on the financial benefits in a general way (without empirical/applied analysis), or to exploring intermediate effects that lead to such financial benefits, like technology and knowledge commercialization (e.g. patents and licenses) and the improvement or creation of products and processes. In this sense, past literature has mainly dedicated to study how UFC affects firm innovation and R\&D outputs.

Taking into account the previous literature on the impact of collaboration with university on firm performance, we hypothesize that UFC should contribute positively to the development and/or improvement of products and processes at firm level, partially following Laursen \& Salter's approach (2006), which should in turn lead to better financial performance. Given the lack of empirical studies on the impact of UFC on the financial performance of firms, we have firstly tried to think of a way to measure such impact. As evidenced throughout this section, UFC has been mainly associated to motivations, types and impacts related to innovation and R\&D at firms. Therefore, we recognise that the generation of value (profits) caused by UFC at firms should mainly take place via innovation and $R \& D$ activities. In this paper we propose the concept of innovation-related profitability, which considers 1) the income generated by the products associated to the innovative efforts of firms and 2) the costs associated to investments on innovation as well as to R\&D personnel and other expenses. Secondly, and bearing in mind that innovative firms can have relevant differences in terms of size, we follow the approach proposed by Grifell-Tatjé \& Lovell $(2015,2016)$, in which the income obtained by the firm for each monetary unit dedicated to innovation is explained. This is a 'profitability' approach that considers the income/cost ratio based on the isolation of inputs and outputs associated to the R\&D and innovation activities of firms, which we recognised as the main factors affected by engagement in UFC. The introduced concept of innovation-related profitability serves as an attempt to measure the contribution of both the efforts (costs) and benefits (revenues) of research and technological development activities to the generation of profits in firms. In this sense, this measure might neglect the contribution of non-R\&D activities and efforts to the development and commercialisation of innovative (new) products, as well as the contribution of R\&D activities and efforts to the production and commercialisation of non-innovative (old) products at firms.

In contrast with the neoclassical view for the impact of UFC on firms that guides our study, relevant literature oriented towards Freeman's 'stakeholder approach' has been 
developed in support of the benefits that other players in regions and nations might get from collaboration for innovation. We cannot neglect to highlight important knowledge developments such as national and regional innovation systems (Lundvall, 1992; Nelson, 1993; Cooke, Uranga, \& Etxebarria, 1997) and the triple/quadruple helix of innovation (Etzkowitz \& Leydesdorff, 1997; Carayannis and Campbell, 2009), in which firms are considered part of an ecosystem and innovation is assessed in a larger spectrum. In these approaches, the needs and benefits of regional stakeholders and the societal impact of $R \& D$ collaborations prevail over its impact on firm performance as the major driver for firms to engage in UFC. The Business Roundtable itself has recently given a turn to its formal position on the 'Purpose of a Corporation ${ }^{\prime 3}$, moving from a predominant and unique focus on shareholders' interests and profits generation towards a more holistic approach in which firms are meant to create value for all stakeholders, including customers, employees, suppliers and communities, with a long-term perspective. This BRT's flip has already received critiques (Winston, 2019), but either if this turn towards social responsibility is about empty rhetoric or real changes in corporate focus in the U.S., we believe firms would always respond primarily to financial motivations when deciding to collaborate with university. Improvements in profitability given by positive changes in firms' productivity thanks to collaboration with university can also lead to industrial development and economic growth at regions via knowledge spillovers (Grossman \& Helpman, 1991) and knowledge exchange (Hughes \& Kitson, 2012).

\section{Methodology}

We are interested in studying the impact of collaboration with university on the innovation-related financial performance of firms. Given the working hypothesis of a UFC's positive impact on firm's innovation-related financial performance, we aim at studying the gain in profitability that collaborating firms might show with respect to non-collaborating firms based on changes in the innovation factors that determine such performance. For this, we follow Grifell-Tatje \& Lovell (2015) and make use of Empirical Index Numbers (EINs) that allow us to decompose and better understand the gain of innovation-related profitability. EINs are estimated using the economic concept of distance functions (Shephard, 1970), which measures the distance between a firm and its best practices frontier or technology. These distance functions are computed through non-parametric programming techniques known as Data Envelopment Analysis (DEA) (Charnes, Cooper \& Rhodes, 1978). The decomposition

\footnotetext{
${ }^{3}$ See https://opportunity.businessroundtable.org/ourcommitment/
} 
of the innovation-related profitability gain provides reference values for the benchmarking model implemented to compare the economic performance of collaborating and non-collaborating firms.

\subsection{Decomposing Innovation-related Profitability Gain}

The concept of innovation-related profitability is proposed in order to answer our first research question regarding the measurement of firm financial performance. For its estimation and decomposition, we firstly define the revenue (R), cost (C) and profitability $(\Pi)$ of collaborating (denoted with 1 ) and non-collaborating (denoted with 0 ) firms under a one input-one output scenario considering their output prices $(p)$ and quantities $(\mathrm{y})$ and their input prices $(\mathrm{w})$ and quantities $(\mathrm{x})$.

$\begin{array}{ccc}\text { Revenue } & \text { Cost } & \text { Profitability } \\ R^{1}=p^{1} y^{1} & C^{1}=w^{1} x^{1} & \Pi^{1}=\frac{R^{1}}{C^{1}} \\ R^{0}=p^{0} y^{0} & C^{0}=w^{0} x^{0} & \Pi^{0}=\frac{R^{0}}{C^{0}}\end{array}$

We can then define the change in profitability of collaborating firms with respect to non-collaborating firms, which we actually prefer to denominate profitability gain.

$$
\frac{\Pi^{1}}{\Pi^{0}}=\frac{R^{1} / C^{1}}{R^{0} / C^{0}}=\frac{R^{1} / R^{0}}{C^{1} / C^{0}}
$$

Profitability Gain $=$ Revenue Change $/$ Cost Change

What we see is that this profitability gain is explained by the ratio between revenue change (numerator) and cost change (denominator), and we proceed to express them in terms of quantities and prices.

$$
\frac{R^{1}}{R^{0}}=\frac{p^{1} y^{1}}{p^{0} y^{0}}=\frac{\boldsymbol{y}^{\mathbf{1}}}{\boldsymbol{y}^{\mathbf{0}}} \times \frac{\boldsymbol{p}^{\mathbf{1}}}{\boldsymbol{p}^{\mathbf{0}}}
$$

Revenue Change $=$ Output Quantity Change $\times$ Output Price Change

$$
\frac{C^{1}}{C^{0}}=\frac{w^{1} x^{1}}{w^{0} x^{0}}=\frac{x^{1}}{x^{0}} \times \frac{w^{1}}{w^{0}}
$$

Cost Change $=$ Input Quantity Change $\times$ Input Price Change 
We have that the revenue change is given by the product between output quantity change and output price change, while the cost change is given by the product between input quantity change and input price change. We can now express the profitability gain in terms of quantities and prices.

$$
\frac{\Pi^{1}}{\Pi^{0}}=\frac{R^{1} / C^{1}}{R^{0} / C^{0}}=\frac{R^{1} / R^{0}}{C^{1} / C^{0}}=\frac{\boldsymbol{y}^{1} / \boldsymbol{y}^{\mathbf{0}}}{\boldsymbol{x}^{\mathbf{1}} / \boldsymbol{x}^{\mathbf{0}}} \times \frac{\boldsymbol{p}^{\mathbf{1}} / \boldsymbol{p}^{\mathbf{0}}}{\boldsymbol{w}^{\mathbf{1}} / \boldsymbol{w}^{\mathbf{0}}}
$$

Profitability Gain $=$ Productivity Change $\times$ Price Recovery Change

We conclude that the profitability gain of collaborating firms with respect to noncollaborating firms is defined by the product between productivity change, given by the changes in quantities, and price recovery change, given by the changes in prices, as portrayed in Figure 1.

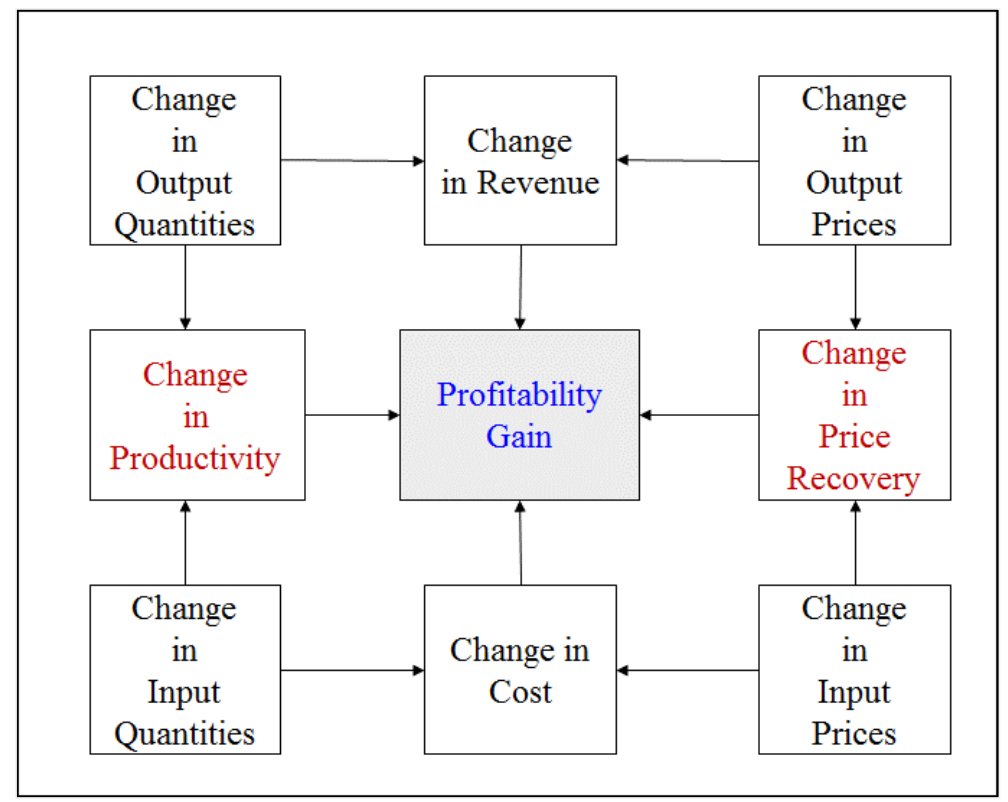

Figure 1 - Grifell-Tatjé \& Lovell's (2015) proposal for the analysis of profitability gain based on van Loggerenberg \& Cucchiaro (1981)

EINs in economics are commonly used to represent the variation of quantities and prices of inputs and outputs between two periods of time. However, in this study we make use of EINs to represent such changes as gaps between firms that collaborate and do not collaborate with university in the same period of time and in a scenario with multiple inputs and outputs. We firstly make use of Laspeyres and Paschee empirical index numbers for output quantity change and output price change 
respectively. Laspeyres Output Quantity Index is defined as $Y_{L}=p^{0 T} y^{1} / p^{0 T} y^{0}$, where $p^{O T}$ represents the transposed vector of input prices from non-collaborating firms, while $y^{1}$ and $y^{\rho}$ represent the vectors of output quantities of collaborating and noncollaborating firms respectively. And Paschee Output Price Index is defined as $P_{P}=$ $y^{1 T} p^{1} / y^{1 T} p^{0}$, where $y^{1 T}$ represents the transposed vector of output quantities from collaborating firms, while $p^{1}$ and $p^{0}$ represent the vectors of output prices of collaborating and non-collaborating firms respectively.

The changes in revenues, costs and profitability between collaborating and noncollaborating firms can be expressed using EINs, as shown in Table 1.

Table 1 - Revenues, Costs and Profitability Change with Empirical Index Numbers

\begin{tabular}{c|c|c|c|} 
& Non-collaborating & Collaborating & Change \\
\hline Revenues & $R^{0}=p^{0 T} y^{\rho}$ & $R^{1}=p^{1 T} y^{1}$ & $R^{1} / R^{O}=p^{1 T} y^{1} / p^{0 T} y^{0}$ \\
\hline Cost & $C^{0}=w^{0 T} x^{0}$ & $C^{1}=w^{1 T} x^{1}$ & $C^{1} / C^{0}=w^{1 T} x^{1} / w^{0 T} x^{0}$ \\
\hline Profitability & $\Pi^{0}=R^{0} / C^{0}$ & $\Pi^{1}=R^{1} / C^{1}$ & $\Pi^{1} / \Pi^{0}$ \\
\hline
\end{tabular}

EINs must comply with the 'Product Test', according to which the product between an output quantity index and an output price index must be equivalent to the change in revenues, while the product between an input quantity index and an input price index must be equivalent to the change in costs. However, this does not occur when using EINs of the same type. For instance, $Y_{L} \times P_{L} \neq R^{1} / R^{0}$ and $X_{L} \times W_{L} \neq C^{1} / C^{0}$ when using Laspeyres indexes uniquely. For this reason, we must combine the use of Laspeyres and Paschee index numbers in order to get that $Y_{L} \times P_{P}=R^{1} / R^{O}$ or $Y_{P} \times P_{L}=R^{1} / R^{O}$.

We can now come back to explaining the changes in revenues and costs using EINs. On the outputs side, we have that the revenue change can be expressed as the product between a Laspeyres Output Quantity Index and a Paschee Output Price Index.

$$
\mathrm{R}^{1} / \mathrm{R}^{0}=\mathrm{Y}_{\mathrm{L}} \times \mathrm{P}_{\mathrm{p}}
$$

Revenue Change $=$ Output Quantity Change $\times$ Output Price Change

Where Laspeyres index can be expressed as $Y_{L}=Y_{M}^{0}\left(x^{0}, y^{1}, y^{0}\right) \times Y M_{M}^{0}\left(x^{0}, p^{0}, y^{1}, y^{0}\right)$ and defined using the economic concept of output-oriented distance functions (Shephard, 1970) as: 


$$
Y_{L}=\frac{D_{o}^{0}\left(x^{0}, y^{1}\right)}{D_{o}^{0}\left(x^{0}, y^{0}\right)} \times \frac{p^{0 T}\left[y^{1} / D_{o}^{0}\left(x^{0}, y^{1}\right)\right]}{p^{0 T}\left[y^{0} / D_{o}^{0}\left(x^{0}, y^{0}\right)\right]}
$$

Which generates that the revenue change can be written as:

$$
\frac{R^{1}}{R^{0}}=\left[\frac{D_{o}^{0}\left(x^{0}, y^{1}\right)}{D_{o}^{0}\left(x^{0}, y^{0}\right)} \times \frac{p^{0 T}\left[y^{1} / D_{o}^{0}\left(x^{0}, y^{1}\right)\right]}{p^{0 T}\left[y^{0} / D_{o}^{0}\left(x^{0}, y^{0}\right)\right]}\right] \times \frac{y^{1 T} p^{1}}{y^{1 T} p^{0}}
$$

Analogically, on the inputs side we have that the cost change can be expressed as the product between a Laspeyres Input Quantity Index and a Paschee Input Price Index.

$$
C^{1} / C^{0}=X_{L} \times W_{p}
$$

Cost Change $=$ Input Quantity Change $x$ Input Price Change

Where Laspeyres index can be expressed as $X_{L}=X_{M}^{0}\left(y^{0}, x^{1}, x^{0}\right) \times X M_{M}^{0}\left(y^{0}, w^{0}, x^{1}, x^{0}\right)$ and defined using input-oriented distance functions (Shephard, 1970) as:

$$
X_{L}=\frac{D_{i}^{0}\left(y^{0}, x^{1}\right)}{D_{i}^{0}\left(y^{0}, x^{0}\right)} \times \frac{w^{0 T}\left[x^{1} / D_{i}^{0}\left(y^{0}, x^{1}\right)\right]}{w^{0 T}\left[x^{0} / D_{i}^{0}\left(y^{0}, x^{0}\right)\right]}
$$

Which generates that the cost change can be written as:

$$
\frac{C^{1}}{C^{0}}=\left[\frac{D_{i}^{0}\left(y^{0}, x^{1}\right)}{D_{i}^{0}\left(y^{0}, x^{0}\right)} \times \frac{w^{0 T}\left[x^{1} / D_{i}^{0}\left(y^{0}, x^{1}\right)\right]}{w^{0 T}\left[x^{0} / D_{i}^{0}\left(y^{0}, x^{0}\right)\right]}\right] \times \frac{x^{1 T} w^{1}}{x^{1 T} w^{0}}
$$

With the changes in revenue and cost being defined, we can now express the profitability gain in terms of Laspeyres and Paschee EINs.

$$
\frac{R^{1} / R^{0}}{C^{1} / C^{0}}=\frac{Y_{L}}{X_{L}} \times \frac{P_{p}}{W_{p}}
$$

Profitability Gain $=$ Productivity Gap x Price Recovery Gap

Therefore, this profitability gain can be expressed using distance functions (Shephard, 1970) as: 


$$
\begin{aligned}
\frac{R^{1} / R^{0}}{C^{1} / C^{0}}= & {\left[\frac{D_{o}^{0}\left(x^{0}, y^{1}\right) / D_{o}^{0}\left(x^{0}, y^{0}\right)}{D_{i}^{0}\left(y^{0}, x^{1}\right) / D_{i}^{0}\left(y^{0}, x^{0}\right)} \times \frac{p^{0 T}\left[y^{1} / D_{o}^{0}\left(x^{0}, y^{1}\right)\right] / p^{0 T}\left[y^{0} / D_{o}^{0}\left(x^{0}, y^{0}\right)\right]}{w^{0 T}\left[x^{1} / D_{i}^{0}\left(y^{0}, x^{1}\right)\right] / w^{0 T}\left[x^{0} / D_{i}^{0}\left(y^{0}, x^{0}\right)\right]}\right] } \\
& \times\left[\frac{y^{1 T} p^{1} / y^{1 T} p^{0}}{x^{1} w^{1} / x^{1} w^{0}}\right]
\end{aligned}
$$

\section{[Bjurek Malmquist Productivity Change x Based Period Mix Effect] $x$ [Price Recovery Gap]}

We then implement Grifell-Tatjé and Lovell approach (2015; $p$ 137) based on a previous proposal of Lovell (2003), according to which the Bjurek Malmquist Productivity Change expression can be redefined as:

$$
\left[\frac{D_{o}^{0}\left(x^{0}, y^{1}\right) / D_{o}^{0}\left(x^{0}, y^{0}\right)}{D_{i}^{0}\left(y^{0}, x^{1}\right) / D_{i}^{0}\left(y^{0}, x^{0}\right)}\right]=\left[\frac{D_{o}^{1}\left(x^{1}, y^{1}\right)}{D_{o}^{0}\left(x^{0}, y^{0}\right)} \times \frac{D_{o}^{0}\left(x^{1}, y^{1}\right)}{D_{o}^{1}\left(x^{1}, y^{1}\right)}\right] \times\left[\frac{D_{o}^{0}\left(x^{0}, y^{1}\right) / D_{o}^{0}\left(x^{1}, y^{1}\right)}{D_{i}^{0}\left(y^{0}, x^{1}\right) / D_{i}^{0}\left(y^{0}, x^{0}\right)}\right]
$$

$=[C D D$ Malmquist Productivity Index $] \times[$ Size Change Effect $]$

\section{$=$ [Output-oriented Technical Efficiency Gap $\times$ Technology Gap] $\times$ [Size Change Effect]}

This leads to the next expression of Profitability Gain:

$$
\begin{aligned}
\frac{R^{1} / R^{0}}{C^{1} / C^{0}}=\left[\frac{D_{o}^{1}\left(x^{1}, y^{1}\right)}{D_{o}^{0}\left(x^{0}, y^{0}\right)} \times \frac{D_{o}^{0}\left(x^{1}, y^{1}\right)}{D_{o}^{1}\left(x^{1}, y^{1}\right)} \times \frac{D_{o}^{0}\left(x^{0}, y^{1}\right) / D_{o}^{0}\left(x^{1}, y^{1}\right)}{D_{i}^{0}\left(y^{0}, x^{1}\right) / D_{i}^{0}\left(y^{0}, x^{0}\right)}\right] \\
\quad \times\left[\frac{p^{0 T}\left[y^{1} / D_{o}^{0}\left(x^{0}, y^{1}\right)\right] / p^{0 T}\left[y^{0} / D_{o}^{0}\left(x^{0}, y^{0}\right)\right]}{w^{0 T}\left[x^{1} / D_{i}^{0}\left(y^{0}, x^{1}\right)\right] / w^{0 T}\left[x^{0} / D_{i}^{0}\left(y^{0}, x^{0}\right)\right]}\right] \times\left[\frac{y^{1 T} p^{1} / y^{1 T} p^{0}}{x^{1} w^{1} / x^{1} w^{0}}\right]
\end{aligned}
$$

Finally, we decide to merge the Size Change Effect and the Based Period Mix Effect and get an adoption of a Size-Scale Effect term "that measures the productivity impact of size change that captures the joint impacts of economies of scale and diversification"(Grifell-Tatjé \& Lovell, 2015, p. 346) to the context of profitability gain. This extension generates an expression related to the size and scale of operations:

$$
\frac{p^{0 T}\left[y^{1} / D_{o}^{0}\left(x^{1}, y^{1}\right)\right] / p^{0 T}\left[y^{0} / D_{o}^{0}\left(x^{0}, y^{0}\right)\right]}{w^{0 T} x^{1} / w^{0 T} x^{0}}
$$

We finally end up with this decomposition of Profitability Gain: 


$$
\begin{gathered}
\frac{R^{1} / R^{0}}{C^{1} / C^{0}}=\left[\frac{D_{o}^{1}\left(x^{1}, y^{1}\right)}{D_{o}^{0}\left(x^{0}, y^{0}\right)} \times \frac{D_{o}^{0}\left(x^{1}, y^{1}\right)}{D_{o}^{1}\left(x^{1}, y^{1}\right)}\right] \\
\times\left[\frac{p^{0 T}\left[y^{1} / D_{o}^{0}\left(x^{1}, y^{1}\right)\right] / p^{0 T}\left[y^{0} / D_{o}^{0}\left(x^{0}, y^{0}\right)\right]}{w^{0 T} x^{1} / w^{0 T} x^{0}}\right] \times\left[\frac{y^{1 T} p^{1} / y^{1 T} p^{0}}{x^{1} w^{1} / x^{1} w^{0}}\right]
\end{gathered}
$$

Profitability Gain = [Malmquist CDD Productivity Index]

x Size-Scale Effect x Price Recovery Gap

Profitability Gain = Technical Efficiency Gap x Technology Gap

$x$ Size-Scale Effect $x$ Price Recovery Gap

The Technical Efficiency Gap compares how efficient are collaborating and noncollaborating firms with respect to their respective technologies or best practices frontiers, as represented in Figure 2.

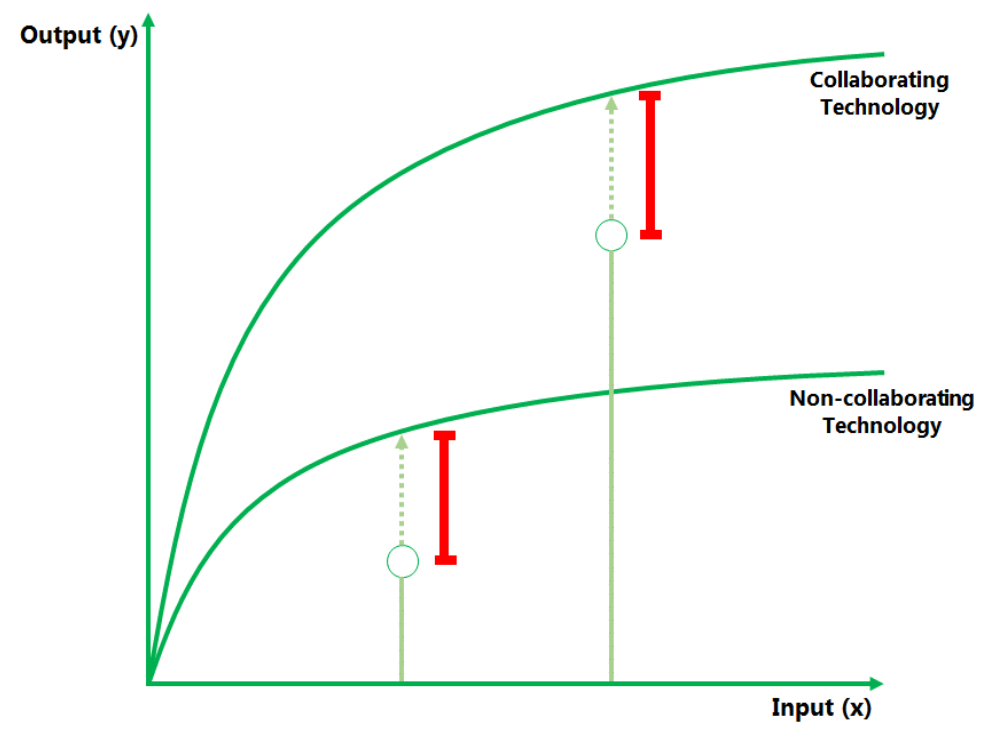

Figure 2 - Representation of Technical Efficiency Gap

The Technology Gap explains the difference between the technologies or best practices frontiers of collaborating and non-collaborating firms, as represented in Figure 3. 


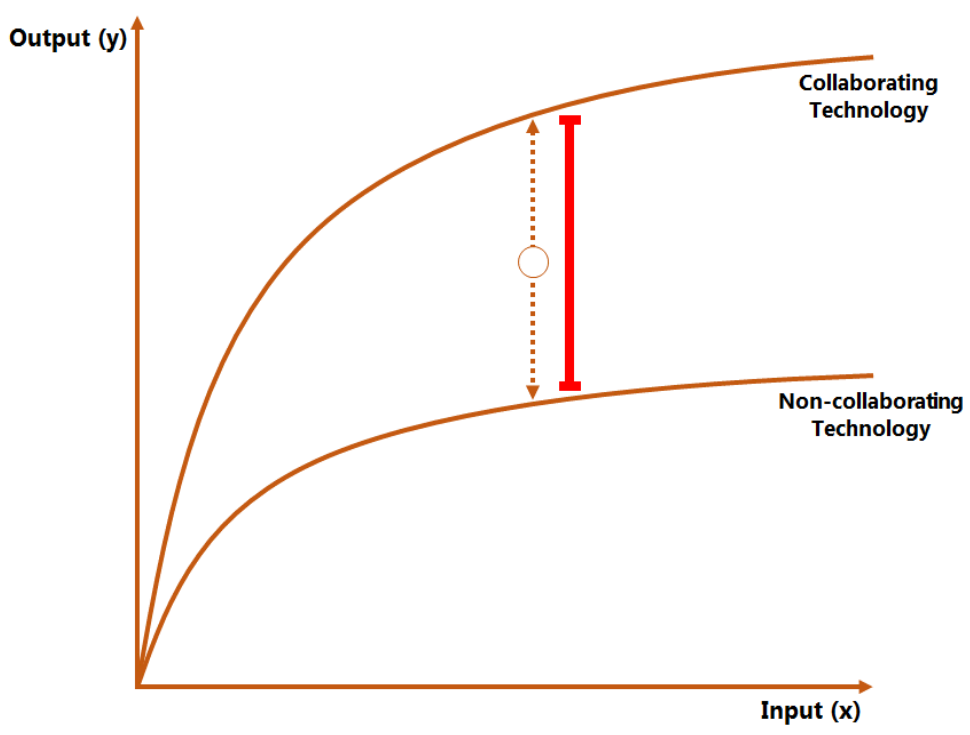

Figure 3 - Representation of Technology Gap

Finally, the Size-Scale Effect explains the differences in the exploitation of economies of scale given by size changes between collaborating and non-collaborating firms, as represented in Figure 4.

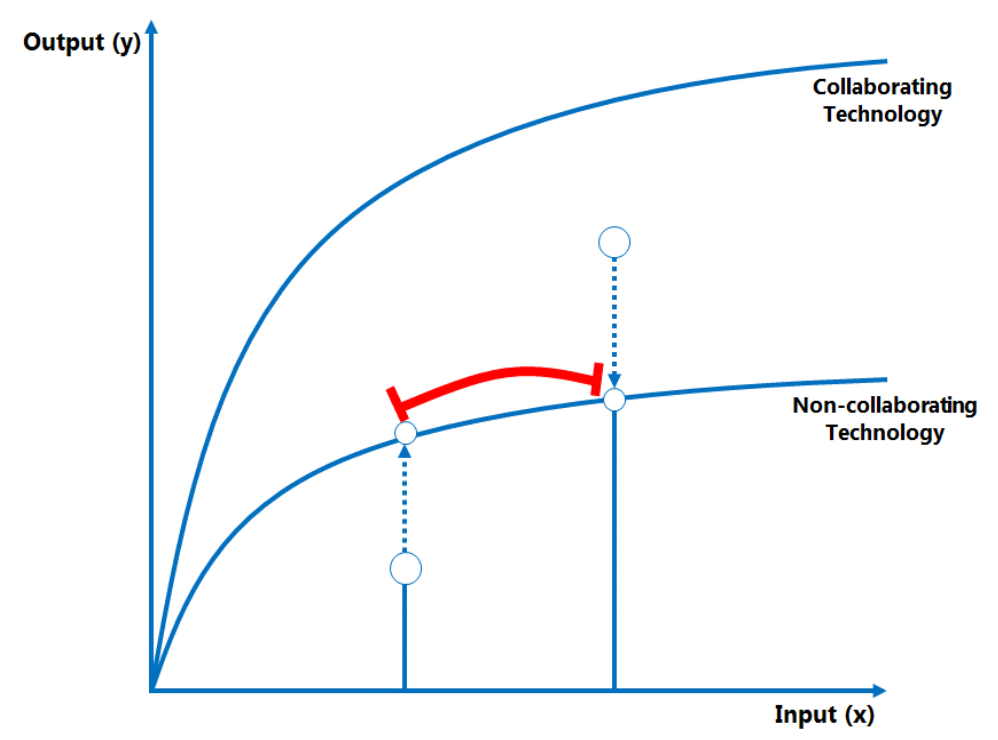

Figure 4 - Representation of Size-Scale Effect

The Price Recovery Gap reflects solely on the differences in prices of inputs and outputs between collaborating and non-collaborating and its effect on the revenues and costs related to the production and commercialisation of innovative products. 


\subsection{Testing and Benchmarking the Gaps}

In order to analyse how significant are the differences in innovation related profitability between collaborating and non-collaborating firms, as per our second research question, we firstly execute parametric (t-tests) methods to test if the mean of profitability differs between the two groups for the studies period in a statistical significant way. We do so in order to study the effect and significance of UFC in the estimation of firm performance.

There are not many antecedents of the use of benchmarking models to compare firm performance in relation to $R \& D$ and innovation activities, and elaborated empirical comparisons based on R\&D collaboration with external partners such as university, for instance, are inexistent to our knowledge. Most common benchmarking exercises have taken care of assessing and comparing new product development practices at firms (Griffin, 1997), basing comparisons on the best and average observations. As more sophisticated methods for benchmarking using DEA measures have been developed (Bogetoft \& Otto, 2011), our study aims at comparing collaborating and noncollaborating firms based on the decomposition of the innovation-related profitability gain explained in the previous section and portrayed in Figure 5.

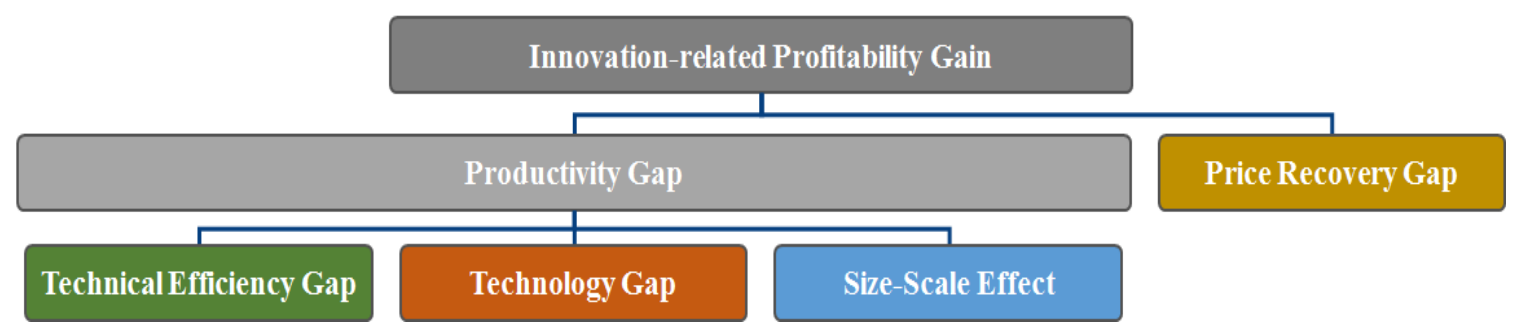

Figure 5 - Measures of Reference for Benchmarking based on Grifell-Tatjé \& Lovell (2015)

We generate a set of simulated representative observations for collaborating and noncollaborating firms for each of the years in the studied period:

- Representative average firms: Average firms are simulated using the means of the quantities and prices of collaborating and non-collaborating groups for computing their revenues, costs and profitability separately.

- Representative profitable firms: Profitable firms are simulated using the means of the quantities and prices for the most profitable quartile of collaborating and non-collaborating groups for computing their revenues, costs and profitability separately. 


\section{Assessing the Impact of University-Firm Collaboration on Innovation-related Financial Performance}

Consequently, four scenarios of comparison are performed among the different benchmarks for computing the innovation-related profitability gain and its components for:

1) Representative average collaborating firm over representative average noncollaborating firm, reflecting on the profitability gain between the middling firms from the two groups.

2) Representative profitable collaborating firm over representative profitable non-collaborating firm, reflecting on the profitability gain between the most profitable firms from the two groups.

3) Representative profitable collaborating firm over representative average non-collaborating firm, reflecting on the profitability gain of the most profitable collaborating firms over the middling non-collaborating firms.

4) Representative average collaborating firm and representative profitable noncollaborating firm, reflecting on the profitability gain of the middling collaborating firms over the most profitable non collaborating firms.

Scenarios 1 and 2 compare firms from the two groups under similar conditions. Moreover, scenario 3 compares collaborating firms in a privileged condition with noncollaborating firms in a regular condition, while scenario 4 compares collaborating firms in a regular condition with non-collaborating firms in a privileged condition.

\section{Data and Variables}

We use data from the Spanish Panel of Technological Innovation (PITEC), which provides information related to research and technological development activities of Spanish firms following the standard of the community innovation survey conducted in many countries of Europe. We analyse a sample of firms from the chemicals industry in Spain between 2005 and 2015. After ensuring complete information and excluding outliers, we get an unbalanced panel data set of 1060 observations for the 11-years period, counting with 119 unique firms across the panel. We also use data from the Spanish National Statistics Institute (INE), from where information on industrial price indexes, minimum wages and capital depreciation rates, among other parameters of the Chemicals industry used to estimate our variables, are retrieved. The chemicals industry was selected mainly because 1 ) it has been identified as one of the most R\&D intensive sectors in Spain according to PITEC data, 2) it counts with one of the largest proportions of collaborating firms in the national spectrum. Therefore, this sector is ideal for assessing the impact of collaboration with university on firm performance, as previously explored in a case study by Manrique (2018). Figure 6 shows the sample distribution between collaborating and non-collaborating firms along the studied 


\section{Assessing the Impact of University-Firm Collaboration on Innovation-related Financial Performance}

period, having that approximately between a third and fourth part of firms collaborate every year.

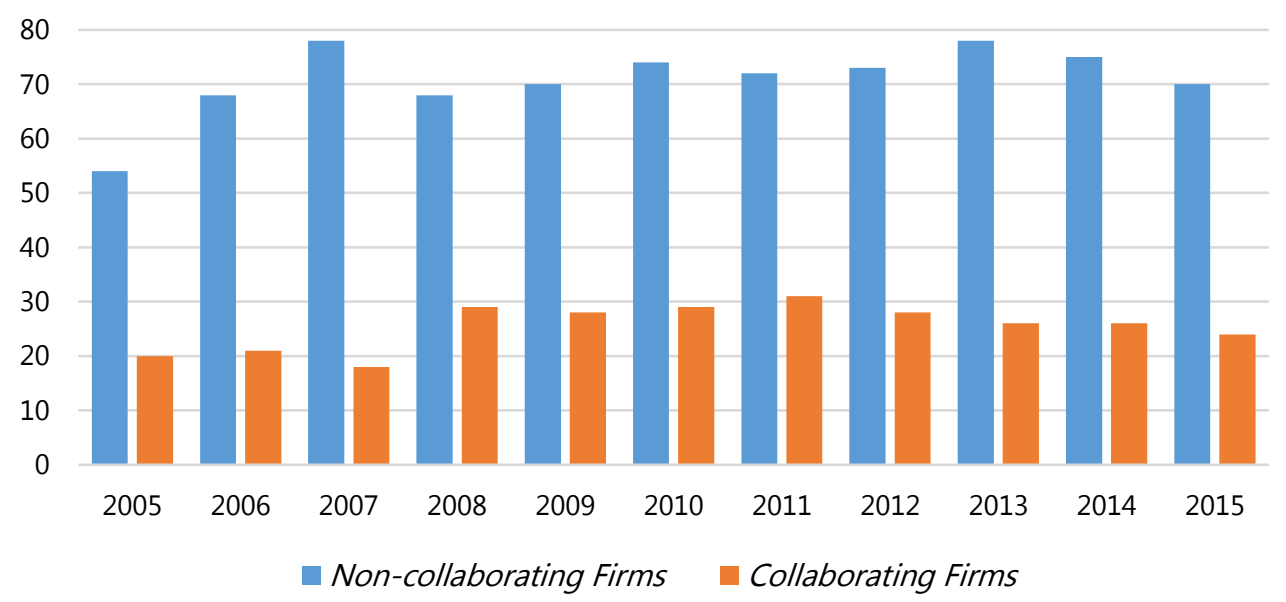

Figure 6 - Number of Observations per Year and Group

Given the methodological approach explained above, we consider a mix of three inputs and two outputs related to R\&D at firms, and their contribution to the innovationrelated profitability of firms. Considering this set of inputs and outputs with its prices, the costs and revenues associated to innovation activities at firms are also computed together with the correspondent profitability as a proxy of innovation-related financial performance. The construction and estimation ${ }^{4}$ of such R\&D factors using PITEC database is explained in detail below.

\footnotetext{
${ }^{4}$ For the quantities of inputs and outputs, the variables have been smoothed by computing the average quantity for periods $\mathrm{t}-1$ and $\mathrm{t}$, and assigning this quantity to period $\mathrm{t}$, in order to remove noise from the data set and allow for trends and patterns to emerge. Additionally, we have observed many extreme and rare values in some of our variables of interest. Such unusual observations might be caused by the nature of our data, which comes from surveys that might allow for human mistakes and mistaken reported information. Thus, these very unusual, extreme and/or rare observations should be excluded in order to remove noise from mistaken information in our analysis. These has been done in two ways: 1) For some variables, outliers have been excluded following an statistical approach (Hoaglin, Iglewicz \& Tukey, 1986) which considers only the observations within the interval [ Mean $-3^{*}$ St. Deviation, Mean $+3^{*}$ St. Deviation], and 2) for variables with senseless values we have stablished some rules in order to exclude mistaken information:

- For the unit cost of labour $\left(\mathrm{W}_{\mathrm{L}}\right)$, we have determined an inferior limit based on the legal monthly minimum wage in Spain for each year.

- For the amount of capital $\left(\mathrm{x}_{\mathrm{K}}\right)$, we have excluded observations with zero value, since we assume that firms without working capital should not be able to generate any innovative products.

- Considering the total sales of a firm as a proxy of size, we have excluded enterprises that are considered micro-firms because such firms normally do not report data on labour and investments of capital in R\&D. Firms with total sales lower than $€ 2$ million have been taken out.
} 


\subsection{Inputs Definition}

The Innovation Personnel in Research $\left(x_{L R}\right)$ and Technological Development $\left(x_{L T D}\right)$ includes the workforce used by each company dedicated to research and technological development activities respectively. These two inputs are measured in number of people employed in each activity per year for each firm. This category may include but is not limited to researchers, technicians and support staff working on scientific research (both basic and applied) and technological development. We firstly take the total number of employees dedicated to R\&D and innovation activities for each firm (PIDT in PITEC) and multiply it for the proportion of current expenses (labour expenses) that each firm allocates to fundamental and applied research (INFUN and INAPL in PITEC) or technological development (DESTEC in PITEC), in order to get the number of employees dedicated to each of these two duties for each firm for each year. Regarding the Innovation Personnel Unit Cost $\left(\boldsymbol{W}_{L R}=\boldsymbol{W}_{L T D}\right)$ and bearing in mind that the information provided by PITEC does not allow us to differentiate among the labour unit cost of workers dedicated to different duties within the R\&D and innovation activities of a firm (basic/applied research VS technological development), we compute a unique personnel unit cost in EUR $(€)$ for each firm in each year, which will serve as price for the two labour inputs considered in this study. In order to estimate the Innovation Personnel Unit Cost, we firstly take the value of the total expenses in research and technological development (GTINN in PITEC) and multiply it for the percentage of these total expenses that are internal (GINTID in PITEC), in order to get the value of the total internal expenses in research and technological development. Then we take this value and multiply it for the percentage of total internal expenses that corresponds to current expenses (TCOR in PITEC), in order to get the value of total current expenses (total labour cost) per firm per year. Finally, we take this value and divide it by the total number of employees working in research and technological development $\left(X_{L B R}+X_{L T D}\right)$, in order to get an average labour unit cost for the innovation personnel.

The Amount of R\&D and Innovation Capital $\left(\boldsymbol{x}_{\boldsymbol{K}}\right)$ considers the investment efforts in research and technological development, and it is measured in units of capital. This includes all investments and expenses in innovation and R\&D activities which are not included in the three previous inputs, that is, all the R\&D and innovation efforts apart from current expenses (human capital expenses). This category includes but is not limited to investments and expenses associated to buildings, software, machinery, labs and tools used by each firm to conduct research and technological development activities in each year. We firstly construct the capital stock for each period. The capital stock of period $\boldsymbol{t}$ is computed by taking the capital stock of the previous period and 


\section{Assessing the Impact of University-Firm Collaboration on Innovation-related Financial Performance}

discounting the depreciation with a weighted average rate that considers the proportion of buildings, machines and software used by the firm, as previously done in a BBVA-IVIE foundation study (2009). This value is then updated using the Price Index of the Chemicals industry, retrieved from INE, as deflator. We then add all the investments (non-current expenses) carried out by the company in period $t$ and value this amount at constant 2005 prices, by applying the deflator cumulatively from 2005 to year t .Regarding the R\&D and Innovation Capital Unit Cost ( $\boldsymbol{w}_{\boldsymbol{k}}$ ), it corresponds to the unit price of the innovation-related working capital and it is measured in EUR $(€)$. This unit price is computed by means of the weighted average cost of capital $\left(W A C C=\%\right.$ Debt ${ }^{*}$ Cost of Debt $+\%$ Equity * Cost of Equity $)$, which assuming zero debt and full financing via equity corresponds to the cost of equity. We calculate the cost of equity by using the capital asset pricing model (CAPM), which considers that $r_{e}$ $=r_{f}+B^{*}\left(r_{m}-r_{f}\right)$. For each year, $\boldsymbol{r}_{\boldsymbol{f}}($ risk free) is estimated using the returns from German government bonds, $\boldsymbol{r}_{\boldsymbol{m}}$ (market return) is estimated using the returns of the Spanish market based on the Euro Stoxx 50 Index, and $\boldsymbol{B}$ (Chemicals sector risk) is retrieved from Madrid Stock Exchange reports. The total cost of financing corresponds to $F=$ $W A C C{ }^{*} x_{K}$ and therefore we find the unit price as $w_{K}=F / x_{K}=W A C C_{1}$ which is transversal across all firms in the Chemicals industry in each year.

\subsection{Outputs Definition}

The Incrementally Innovative Products ( $\left.\boldsymbol{y}_{I N C}\right)$ and Radically Innovative Products $\left(y_{R A D}\right)$ reflects on the produced amount of innovative products new to the firm and new to the market respectively. A product is new or novel as long as it has been introduced between $\boldsymbol{t}-\mathbf{1}$ and $\boldsymbol{t}$. We firstly estimate the value of total revenues from products new to the firm or new to the market by multiplying the total sales (CIFRA in PITEC) of a firm in a certain year by the percentage of such sales that corresponds to products new to the firm (NEWEMP in PITEC) or new to the market (NEWMAR in PITEC), getting the total revenues from incremental or radical innovation. The quantity of incrementally or radically innovative products is estimated with the deflated value of revenues from incremental or radical innovation, dividing such revenues by $1+D_{Y_{1}}$ where $D_{Y}$ corresponds to the compound price index of the chemicals industry, that is, the cumulative variation of prices in the chemicals industry, which is retrieved from the Spanish National Statistics Institute (INE). Regarding the Unit Price of Incrementally Innovative Products $\left(p_{I N C}\right)$ and Radically Innovative Products $\left(p_{R A D}\right)$, these are measured in EUR $(€)$ for each year and each firm. Such unit price is computed by dividing the total non-deflated and smoothed revenues from incrementally or radically innovative products by the smoothed quantity of incrementally or radically innovative production $\left(y_{I N C}\right.$ or $\left.y_{R A D}\right)$. In the end, this price corresponds to the cumulative variation 


\section{Assessing the Impact of University-Firm Collaboration on Innovation-related Financial Performance}

of prices in the chemicals industry. We are therefore using a deflator that captures the prices behaviour of the chemicals industry as a proxy of output unit cost.

\subsection{Explanatory Variable}

University-Firm Collaboration (UFC) is a binary variable that takes the value of 1 in period $\boldsymbol{t}$ if the firm has conducted any collaboration with a higher education or research institution between $\boldsymbol{t}-\mathbf{2}$ and $\boldsymbol{t}$, and the value of 0 otherwise. In this sense, this study analyses the impact of collaboration with university between $\boldsymbol{t}$ - $\boldsymbol{2}$ ant $\boldsymbol{t}$ on the innovation-related financial performance of $\boldsymbol{t}$.

\section{Results}

We firstly present a descriptive summary of our provisional results in Table 2, based on the averages of the different variables of interest for the whole studied period (2005-2015), for which 280 and 780 out of 1,060 observations correspond to collaborating and non-collaborating firms respectively. Considering the total revenues (from both innovative and non-innovative products) as a proxy of size, we observe that collaborating firms are, in average, more than twice larger than noncollaborating firms, reflecting on the higher likeliness of larger firms to collaborate with university, as mentioned in the conceptual framework. In these preliminary results we also observe that the participation of innovative products in the total sales of firms is slightly higher for non-collaborating firms, but for the two groups close to $30 \%$ of the total sales correspond to innovative products, reflecting on the R\&D intensity and innovation performance of the chemicals industry of Spain in general.

Table 2 - Summary of Averages for the Variables of Interests

\begin{tabular}{|c|c|c|c|}
\hline & Collaborating Firms (1) & & Non-Collaborating Firms (0) \\
\hline \# of Observations & 280 & $<$ & 780 \\
\hline Total Revenues (Size Proxy) & $88,579,117.26 €$ & $>$ & $39,893,333.02 €$ \\
\hline Innovative Sales/Total Sales & 0.29 & $<$ & 0.30 \\
\hline yINC & $8,673,156.61$ & $>$ & $5,048,423.29$ \\
\hline$y_{R A D}$ & $5,784,753.20$ & $>$ & $2,540,474.59$ \\
\hline PINC & $1.33 €$ & $\approx$ & $1.32 €$ \\
\hline$p_{R A D}$ & $1.33 €$ & $\approx$ & $1.33 €$ \\
\hline$X_{L R}$ & 10.80 & $>$ & 6.37 \\
\hline$X_{L T D}$ & 8.02 & $>$ & 5.65 \\
\hline $\boldsymbol{x}_{K}$ & $1,168,066.77$ & $>$ & $550,774.24$ \\
\hline
\end{tabular}




\section{Assessing the Impact of University-Firm Collaboration on Innovation-related Financial Performance}

\begin{tabular}{|c|c|c|c|}
\hline$w_{L R}$ & $43,708.25 €$ & $>$ & $39,113.20 €$ \\
\hline$w_{L T D}$ & $43,708.25 €$ & $>$ & $39,113.20 €$ \\
\hline$w_{K}$ & $0.05 €$ & $\approx$ & $0.05 €$ \\
\hline Innovation-related Revenues & $19,178,523.59 €$ & $>$ & $10,032,838.65 €$ \\
\hline Innovation-related Costs & $884,555.49 €$ & $>$ & $499,686.46 €$ \\
\hline Innovation-related Profit & $18,293,968.10 €$ & $>$ & $9,533,152.19 €$ \\
\hline Innovation-related Profitability & 21.68 & $>$ & 20.08 \\
\hline
\end{tabular}

Moving on to our provisional results on the quantities and prices of inputs and outputs, we firstly observe that the quantities of both incrementally and radically innovative products $\left(y_{I N C}\right.$ and $y_{R A D}$ ) are significantly larger for collaborating-firms. Output prices ( $p_{I N C}$ and $p_{R A D}$ ) do not show differences as such prices have been estimated using a cumulative deflator that captures the behaviour of prices in the industry, affecting the two groups equally. On the outputs side, we conclude that the average innovationrelated revenues of collaborating firms double those of non-collaborating firms. With respect to the inputs, the quantities of both research and technological development staff $\left(x_{L R}\right.$ and $\left.X_{L T D}\right)$ are higher for collaborating firms, indicating that collaborating firms attract and hire, in average, more R\&D personnel. Additionally, the labour unit cost $\left(W_{L}\right)$ is also higher for collaborating firms, reflecting that collaborating firms, in average, pay better to their R\&D employees. The amount of innovation capital $\left(x_{k}\right)$ used by collaborating firms is more than two times the amount used by non-collaborating firms, indicating that collaborating firms, in average, invest a lot more in R\&D than non-collaborating firms. Capital unit price $\left(w_{k}\right)$ does not show differences as such price has been estimated using WACC model for the whole chemicals sector. On the inputs side, we conclude that the average innovation-related costs of collaborating firms are significantly higher than those of non-collaborating firms. In the end, the previous results cause that the innovation-related profit $(R-C)$ of collaborating firms doubles the one of noncollaborating firms, and more importantly, the average innovation-related profitability is nearly $\mathbf{8 \%}$ higher for collaborating firms. Consequently, it is worth to observe the behaviours of such profitability for the two groups in each of the years of the observed period, as represented in Figure 7. 


\section{Assessing the Impact of University-Firm Collaboration on Innovation-related Financial Performance}

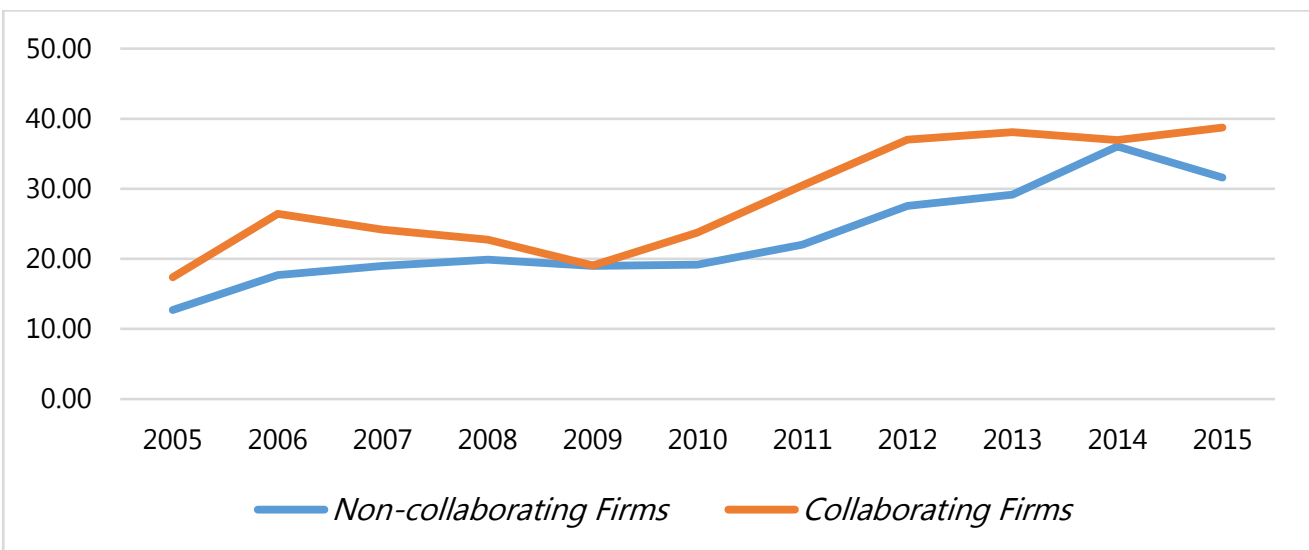

Figure 7 - Profitability of Non-Collaborating and Collaborating Firms per year (2005-2015)

Excepting 2009 and 2014, in which the profitability of the two groups is very similar, we observe that in every year collaborating firms perform a higher innovationrelated profitability than non-collaborating firms. However, we are also interested in knowing how statistically significant is this difference. The results of the t-test performed in this regard are shown in Table 3. From this test, we can conclude that the innovation-related profitability of collaborating firms is significantly higher than the innovation-related profitability of non-collaborating firms under a $5 \%$ significance level.

Table 3 - t-test for Profitability Mean Difference

\begin{tabular}{|c|c|c|c|c|c|c|}
\hline Group & Obs & Mean & Std. Err. & Std. Dev. & [95* Conf. & Interval] \\
\hline 0 & 780 & 23.41362 & 1.303353 & 36.40065 & 20.85512 & 25.97211 \\
\hline 1 & 280 & 28.86857 & 3.007081 & 50.31808 & 22.94912 & 34.78802 \\
\hline combined & 1,060 & 24.85455 & 1.246698 & 40.58955 & 22.40827 & 27.30083 \\
\hline diff & & -5.454956 & 3.277386 & & -11.89858 & .9886639 \\
\hline $\begin{array}{l}\text { diff } \\
\text { Ho: diff }\end{array}$ & $\begin{array}{l}\text { mean }(0) \\
0\end{array}$ & - mean (1) & \multicolumn{2}{|c|}{ Satterthwaite's degrees } & of freedom & $\begin{array}{l}=-1.6644 \\
=388.758\end{array}$ \\
\hline $\begin{array}{r}\text { Ha: } \\
\text { Pr }(T<0\end{array}$ & $\begin{array}{l}\text { ff }<0 \\
=0.0484\end{array}$ & $\operatorname{Pr}($ & \multicolumn{2}{|c|}{$\begin{array}{l}\text { Ha: diff } !=0 \\
T|>| t \mid)=0.0968\end{array}$} & \multicolumn{2}{|c|}{$\begin{aligned} \text { Ha: diff } & >0 \\
\operatorname{Pr}(I>t) & =0.9516\end{aligned}$} \\
\hline
\end{tabular}

After having measured and tested the gain in innovation-related profitability of collaborating over non-collaborating firms, it is now time to present what is behind such differences with the provisional results of our benchmarking exercise given the 


\section{Assessing the Impact of University-Firm Collaboration on Innovation-related Financial Performance}

decomposition of innovation-related profitability and the four scenarios explained in the methodology section. To start, Table 4 presents the results for the first scenario, in which a representative average collaborating firm is compared to a representative average non-collaborating firm.

Table 4 - Benchmarking Scenario 1: Collaborating Average vs Non-collaborating Average

\begin{tabular}{|c|c|c|c|c|c|}
\hline & $\begin{array}{c}\text { Technical } \\
\text { Efficiency Gap }\end{array}$ & $\begin{array}{c}\text { Technology } \\
\text { Gap }\end{array}$ & $\begin{array}{c}\text { Size-Scale } \\
\text { Effect }\end{array}$ & $\begin{array}{c}\text { Price Recovery } \\
\text { Change }\end{array}$ & $\begin{array}{c}\text { Profitability } \\
\text { Gain }\end{array}$ \\
\hline 2005 & 2.701 & 0.672 & 0.839 & 0.946 & $\mathbf{1 . 4 3 9}$ \\
\hline 2006 & 1.252 & 0.879 & 0.775 & 0.866 & $\mathbf{0 . 7 3 8}$ \\
\hline 2007 & 1.291 & 1.160 & 0.916 & 0.820 & $\mathbf{1 . 1 2 6}$ \\
\hline 2008 & 1.026 & 1.717 & 0.851 & 0.906 & $\mathbf{1 . 3 5 7}$ \\
\hline 2009 & 1.386 & 1.353 & 0.739 & 1.104 & $\mathbf{1 . 5 3 0}$ \\
\hline 2010 & 1.297 & 1.014 & 0.905 & 1.092 & $\mathbf{1 . 3 0 0}$ \\
\hline 2011 & 1.791 & 1.083 & 0.879 & 0.853 & $\mathbf{1 . 4 5 5}$ \\
\hline 2012 & 1.078 & 0.889 & 1.141 & 0.864 & $\mathbf{0 . 9 4 4}$ \\
\hline 2013 & 1.158 & 1.214 & 0.847 & 0.792 & $\mathbf{0 . 9 4 4}$ \\
\hline 2014 & 1.921 & 0.466 & 0.835 & 0.908 & $\mathbf{0 . 6 7 9}$ \\
\hline 2015 & 1.372 & 0.983 & 0.800 & 0.847 & $\mathbf{0 . 9 1 4}$ \\
\hline $\mathbf{2 0 0 5 - 2 0 1 5}$ & $\mathbf{1 . 4 7 9}$ & $\mathbf{1 . 0 3 9}$ & $\mathbf{0 . 8 6 6}$ & $\mathbf{0 . 9 0 9}$ & $\underline{\mathbf{1 . 1 3 0}}$ \\
\hline
\end{tabular}

This scenario represents the innovation-related profitability gain of middling collaborating firms over middling non-collaborating firms. Firstly, we observe that in scenario 1 the representative average collaborating firm is, in average, 13\% more profitable than the representative average non-collaborating firm for the studied period. This gain is mainly given by a favourable gap in technical efficiency, as the representative average collaborating firm is, in average, $48 \%$ more technically efficient than the representative average non-collaborating firm. This gain is also partially supported by a favourable technology gap of nearly $4 \%$. However, this gain is also being negatively affected by unfavourable gaps in terms of size-scale effect and price recovery, indicating that changes in prices, size and the scale of operations do not help average collaborating firms to gain profitability as much as they do for average noncollaborating firms. Moving on, Table 5 presents the results for the second scenario, in which a representative profitable collaborating firm is compared to a representative profitable non-collaborating firm. 


\section{Assessing the Impact of University-Firm Collaboration on Innovation-related Financial Performance}

Table 5 - Benchmarking Scenario 2: Collaborating Profitable vs Non-collaborating Profitable

\begin{tabular}{|c|c|c|c|c|c|}
\hline & $\begin{array}{c}\text { Technical } \\
\text { Efficiency Gap }\end{array}$ & $\begin{array}{c}\text { Technology } \\
\text { Gap }\end{array}$ & $\begin{array}{c}\text { Size-Scale } \\
\text { Effect }\end{array}$ & $\begin{array}{c}\text { Price Recovery } \\
\text { Change }\end{array}$ & $\begin{array}{c}\text { Profitability } \\
\text { Gain }\end{array}$ \\
\hline 2005 & 1.875 & 1.193 & 0.664 & 0.938 & $\mathbf{1 . 3 9 3}$ \\
\hline 2006 & 1.603 & 1.096 & 0.661 & 1.167 & $\mathbf{1 . 3 5 6}$ \\
\hline 2007 & 0.992 & 1.359 & 0.912 & 1.010 & $\mathbf{1 . 2 4 2}$ \\
\hline 2008 & 1.049 & 1.950 & 0.592 & 0.817 & $\mathbf{0 . 9 9 0}$ \\
\hline 2009 & 1.997 & 1.344 & 0.531 & 0.988 & $\mathbf{1 . 4 0 8}$ \\
\hline 2010 & 1.127 & 1.022 & 0.821 & 1.211 & $\mathbf{1 . 1 4 6}$ \\
\hline 2011 & 1.733 & 1.109 & 0.717 & 0.972 & $\mathbf{1 . 3 3 9}$ \\
\hline 2012 & 1.217 & 1.103 & 0.887 & 1.122 & $\mathbf{1 . 3 3 6}$ \\
\hline 2013 & 1.253 & 1.112 & 1.033 & 0.770 & $\mathbf{1 . 1 0 9}$ \\
\hline 2014 & 1.876 & 0.606 & 0.641 & 1.139 & $\mathbf{0 . 8 3 1}$ \\
\hline 2015 & 1.535 & 0.926 & 0.911 & 1.065 & $\mathbf{1 . 3 7 8}$ \\
\hline $\mathbf{2 0 0 5 - 2 0 1 5}$ & $\mathbf{1 . 4 7 8}$ & $\mathbf{1 . 1 6 6}$ & $\mathbf{0 . 7 6 1}$ & $\mathbf{1 . 0 1 8}$ & $\underline{\mathbf{1 . 2 3 0}}$ \\
\hline
\end{tabular}

This scenario represents the innovation-related profitability gain of outperforming collaborating firms over outperforming non-collaborating firms. Firstly, we observe that in scenario 2 the representative profitable collaborating firm is, in average, 23\% more profitable than the representative profitable non-collaborating firm for the studied period. This gain is mainly given by a favourable gap in technical efficiency, as the representative profitable collaborating firm is, in average, $48 \%$ more technically efficient than the representative profitable non-collaborating firm. This gain is also partially supported by a favourable technology gap of nearly $17 \%$ and a favourable price recovery gap of $2 \%$, indicating that best practices in the sector as well as changes in prices are more convenient for profitable collaborating firms. However, this gain is also being negatively affected by an unfavourable gaps in terms of sizescale effect, indicating that changes in size and the scale of operations do not help outperforming collaborating firms to gain profitability as much as they do for outperforming non-collaborating firms. Moving on, Table 6 presents the results for the third scenario, in which a representative profitable collaborating firm is compared to a representative average non-collaborating firm. 


\section{Assessing the Impact of University-Firm Collaboration on Innovation-related Financial Performance}

Table 6 - Benchmarking Scenario 3: Collaborating Profitable vs Non-collaborating Average

\begin{tabular}{|c|c|c|c|c|c|}
\hline & $\begin{array}{c}\text { Technical } \\
\text { Efficiency Gap }\end{array}$ & $\begin{array}{c}\text { Technology } \\
\text { Gap }\end{array}$ & $\begin{array}{c}\text { Size-Scale } \\
\text { Effect }\end{array}$ & $\begin{array}{c}\text { Price Recovery } \\
\text { Change }\end{array}$ & $\begin{array}{c}\text { Profitability } \\
\text { Gain }\end{array}$ \\
\hline 2005 & 4.664 & 1.193 & 0.730 & 1.020 & $\mathbf{4 . 1 4 3}$ \\
\hline 2006 & 2.953 & 1.096 & 0.985 & 1.241 & $\mathbf{3 . 9 6 1}$ \\
\hline 2007 & 2.442 & 1.359 & 0.970 & 1.081 & $\mathbf{3 . 4 7 7}$ \\
\hline 2008 & 2.368 & 1.950 & 0.779 & 0.897 & $\mathbf{3 . 2 2 8}$ \\
\hline 2009 & 4.402 & 1.344 & 0.688 & 0.993 & $\mathbf{4 . 0 4 0}$ \\
\hline 2010 & 3.071 & 1.022 & 0.865 & 1.369 & $\mathbf{3 . 7 1 4}$ \\
\hline 2011 & 4.413 & 1.109 & 0.818 & 1.088 & $\mathbf{4 . 3 5 7}$ \\
\hline 2012 & 2.935 & 1.103 & 0.968 & 1.197 & $\mathbf{3 . 7 5 0}$ \\
\hline 2013 & 3.153 & 1.112 & 1.001 & 0.833 & $\mathbf{2 . 9 2 5}$ \\
\hline 2014 & 4.246 & 0.606 & 0.710 & 1.054 & $\mathbf{1 . 9 2 7}$ \\
\hline 2015 & 3.371 & 0.926 & 0.906 & 0.999 & $\mathbf{2 . 8 2 6}$ \\
\hline $\mathbf{2 0 0 5 - 2 0 1 5}$ & 3.456 & 1.166 & $\mathbf{0 . 8 5 6}$ & 1.070 & $\underline{\mathbf{3 . 4 8 6}}$ \\
\hline
\end{tabular}

This scenario represents the innovation-related profitability gain of outperforming collaborating firms over middling non-collaborating firms. Firstly, we observe that in scenario 3 the representative profitable collaborating firm is, in average, 3.5 times more profitable than the representative average non-collaborating firm for the studied period. This gain is mainly given by a favourable gap in technical efficiency, as the representative outperforming collaborating firm is, in average, 3.5 times more technically efficient than the representative middling non-collaborating firm. This gain is also partially supported by a favourable technology gap of nearly $17 \%$, as in scenario 2 , and a favourable price recovery gap of $7 \%$, indicating that best practices in the sector as well as changes in prices are more convenient for profitable collaborating firms. However, this gain is also being negatively affected by an unfavourable gap in terms of size-scale effect, indicating that changes in size and the scale of operations do not help outperforming collaborating firms to gain profitability as much as they do for middling non-collaborating firms. Moving on, Table 7 presents the results for the fourth scenario, in which a representative average collaborating firm is compared to a representative profitable non-collaborating firm. 


\section{Assessing the Impact of University-Firm Collaboration on Innovation-related Financial Performance}

Table 7 - Benchmarking Scenario 4: Collaborating Average vs Non-collaborating Profitable

\begin{tabular}{|c|c|c|c|c|c|}
\hline & $\begin{array}{c}\text { Technical } \\
\text { Efficiency Gap }\end{array}$ & $\begin{array}{c}\text { Technology } \\
\text { Gap }\end{array}$ & $\begin{array}{c}\text { Size-Scale } \\
\text { Effect }\end{array}$ & $\begin{array}{c}\text { Price Recovery } \\
\text { Change }\end{array}$ & $\begin{array}{c}\text { Profitability } \\
\text { Gain }\end{array}$ \\
\hline 2005 & 1.086 & 0.672 & 0.777 & 0.854 & $\mathbf{0 . 4 8 4}$ \\
\hline 2006 & 0.679 & 0.879 & 0.522 & 0.811 & $\mathbf{0 . 2 5 3}$ \\
\hline 2007 & 0.524 & 1.160 & 0.868 & 0.761 & $\mathbf{0 . 4 0 2}$ \\
\hline 2008 & 0.454 & 1.717 & 0.652 & 0.818 & $\mathbf{0 . 4 1 6}$ \\
\hline 2009 & 0.629 & 1.353 & 0.570 & 1.099 & $\mathbf{0 . 5 3 3}$ \\
\hline 2010 & 0.476 & 1.014 & 0.859 & 0.968 & $\mathbf{0 . 4 0 1}$ \\
\hline 2011 & 0.703 & 1.083 & 0.770 & 0.763 & $\mathbf{0 . 4 4 7}$ \\
\hline 2012 & 0.447 & 0.889 & 1.045 & 0.810 & $\mathbf{0 . 3 3 6}$ \\
\hline 2013 & 0.460 & 1.214 & 0.874 & 0.732 & $\mathbf{0 . 3 5 8}$ \\
\hline 2014 & 0.849 & 0.466 & 0.754 & 0.980 & $\mathbf{0 . 2 9 3}$ \\
\hline 2015 & 0.625 & 0.983 & 0.802 & 0.904 & $\mathbf{0 . 4 4 6}$ \\
\hline $\mathbf{2 0 0 5 - 2 0 1 5}$ & $\mathbf{0 . 6 3 0}$ & $\mathbf{1 . 0 3 9}$ & $\mathbf{0 . 7 7 2}$ & $\mathbf{0 . 8 6 4}$ & $\mathbf{0 . 3 9 7}$ \\
\hline
\end{tabular}

This scenario represents the innovation-related profitability gain of middling collaborating firms over outperforming non-collaborating firms. Firstly, we observe that in scenario 4 the representative average collaborating firm is, in average, $60 \%$ less profitable than the representative profitable non-collaborating firm for the studied period, so only in this case we actually have a profitability loss or setback rather than gain. This loss is mainly given by unfavourable gaps in technical efficiency, size-scale effect and price recovery, for which the representative middling collaborating firm is $37 \%, 23 \%$ and $14 \%$ below the representative outperforming noncollaborating firm respectively. This loss, however, is also partially mitigated by a favourable technology gap of nearly $4 \%$, as in scenario 1 , indicating that best practices in the sector are more convenient for average collaborating firms.

\section{Discussion and Conclusions}

The original and main objective of this research was to assess the impact of collaboration with university on the economic performance of firms, based on evidence from firms of the chemicals industry in Spain. Three specific research questions were formulated in order to understand the impact of UFC on firm financial performance more broadly. We firstly recognised that conceptually the potential economic benefits for firms from engaging in UFC should take place via innovation, considering the motivations, types and impacts reviewed in section 2 . Therefore, we 


\section{Assessing the Impact of University-Firm Collaboration on Innovation-related Financial Performance}

firstly asked "how can firm innovation-related financial performance be measured?" and developed a new business economics concept in order to answer it. The innovation-related profitability of firms is based on the isolation of R\&D an innovation-related labour and capital costs used by firms to produce and sell incrementally and radically innovative products, computing a revenues-costs ratio (Grifell-Tatjé \& Lovell, 2015) that allows comparison among firms of different size and characteristics, as explained in section 3. Secondly, we asked "do collaborating and non-collaborating firms have significant differences in terms of innovationrelated financial performance?" and proceeded to compute the innovation-related profitability of collaborating and non-collaborating Spanish chemicals firms for the period between 2005 and 2015. We primarily observed that, in average, the firm financial innovation performance of collaborating firms was nearly $8 \%$ higher than the one of non-collaborating firms. This behaviour could be observed virtually along the whole studied period. A statistical parametric test let us confirm that such difference in profitability was statistically significant.

The performance gap was estimated and decomposed using Empirical Index Numbers and distance functions computed through Data Envelopment Analysis techniques, using a set of inputs and outputs constructed with data from the Spanish community innovation survey. We did so in order to answer our third and final research question in which we asked "how does UFC help to create economic value at firms? does it improve technology and managerial efficiency? and what is the profitability gain associated to such improvements?", decomposing the innovation related profitability in four terms: 1) technical efficiency gap and technology gap, accounting for changes in productivity between collaborating and non-collaborating firms, 2) sizescale effect, reflecting on the changes in size and scale of operations between the two groups, and 4) price recovery gap, reflecting on the changes in the prices of inputs and outputs from the two groups. A set of representative observations were simulated. On one side, middling representative firms were estimated for each group in each year using the average of quantities and prices of inputs and outputs of all firms. On the other hand, outperforming representative firms were estimated for each group in each year using the average of quantities and prices of inputs and outputs of the firms from the most profitable quartile. A benchmarking exercise was developed in order to estimate and analyse the profitability gap and perform comparisons among these representative firms from the collaborating and non-collaborating groups. A summary of the benchmarking results is presented in Table 8 . 


\section{Assessing the Impact of University-Firm Collaboration on Innovation-related Financial Performance}

\begin{tabular}{|c|c|c|}
\hline & $\begin{array}{c}\text { Average } \\
\text { Collaborating Firms }\end{array}$ & $\begin{array}{c}\text { Most Profitable } \\
\text { Collaborating Firms }\end{array}$ \\
\hline & Scenario 1 & Scenario 3 \\
\hline $\begin{array}{c}\text { Average } \\
\text { Non-Collaborating } \\
\text { Firms }\end{array}$ & $\begin{array}{c}+ \text { Technical Efficiency } \\
+ \text { Technology (Best Practices) } \\
\quad-\text { Size-Scale Effect } \\
\quad-\text { Price Recovery } \\
\text { + Innovation-related Profitability }\end{array}$ & $\begin{array}{c}\text { + Technical Efficiency } \\
+ \text { Technology (Best Practices) } \\
\quad-\text { Size-Scale Effect } \\
+ \text { Price Recovery } \\
\text { + Innovation-related Profitability }\end{array}$ \\
\hline & Scenario 4 & Scenario 2 \\
\hline $\begin{array}{c}\text { Most Profitable } \\
\text { Non-Collaborating } \\
\text { Firms }\end{array}$ & $\begin{array}{c}\text { - Technical Efficiency } \\
+ \text { Technology (Best Practices) } \\
\text { - Size-Scale Effect } \\
\text { - Price Recovery } \\
\text { - Innovation-related Profitability }\end{array}$ & $\begin{array}{c}+ \text { Technical Efficiency } \\
+ \text { Technology (Best Practices) } \\
\quad-\text { Size-Scale Effect } \\
+ \text { Price Recovery } \\
\text { + Innovation-related Profitability }\end{array}$ \\
\hline
\end{tabular}

Our findings let us understand how these different components contribute either to support or weaken the performance gain of collaborating over non-collaborating firms. In 3 out of 4 scenarios we observed clear gains in innovation-related profitability for collaborating firms with respect to non-collaborating. Only in the case of comparing middling collaborating firms and outperforming non-collaborating firm we observed a profitability setback, potentially indicating that wealthy firms that do not collaborate with university might not be willing to start collaborating if they cannot ensure a privileged position in terms of financial performance in the collaborating group. We also found that there is a technology gain ranging between $4 \%$ and $17 \%$ for collaborating firms over those that do not collaborate with university. This technology, based on the best practices of each group, seems to be more advanced for firms that collaborate with university. Furthermore, we observed that the innovation-related profitability gain is mainly driven, and in a major extent, by advantages in efficiency of collaborating over non-collaborating firms. On the other hand, the size-scale effect play against collaborating firms in all scenarios. As collaborating firms seem to be way larger in average for our sample, this could indicate non-collaborating firms are in a growing phase in which they can take more advantage of economies of scale, while larger collaborating firms find it more challenging.

In conclusion, provisional results show that firms that collaborate with university are in average more profitable, performing higher sales of both incrementally and radically 
innovative products. However, collaborating firms also show significantly higher innovation capital investments as well as higher R\&D personnel unit costs. These findings may indicate that firms that collaborate with university perform higher innovative sales as the result of significantly higher efforts in terms of innovationrelated capital and personnel investments. Especially when compared to a representative outperforming collaborating firm, a positive gain is clearly observed with respect to non-collaborating firms. This gain from collaborating is given mainly by advantages in technical efficiency and secondly by a more advanced technology. The size-scale effect and the price recovery gap do not contribute positively to the profitability gain. In brief, it is possible to say that collaborating firms are more profitable given to their better performance in terms of productivity, and in general, our evidence show that UFC is more likely to help to create economic value at firms.

\subsection{Policy Implications}

Industrial policy should bear in mind the potential gain from collaboration with university in firms' financial performance via technical efficiency and technology, which could generate a positive effect in the sectorial industrial productivity. We dare to suggest that regional innovation productivity could somehow be indirectly impacted by UFC through the cumulative profitability gains generated by collaboration for innovation with university at firm-level, and this hypothesis should motivate further research on this issue. Consequently, regional innovation policies which currently provide a key role to universities, could complement this approach with a wider focus on the potential economic benefits of UFC on industry.

Furthermore, higher education policy could promote more incisively a boost in UFC based on evidence like the one provided in this work. There is a great unexplored potential for win-win relationships between firms and universities, in which engagement in UFC from firms' perspective can be justified in economic terms according to Friedman's and BRT's neoclassical view. Academia cannot fail in communicating and sensitising managers and practitioners on the potential economic benefits via innovation from collaboration with university, and through this article, we contribute to broadening the understanding of the impact of UFC on firm performance in economic terms and with empirical evidence. 


\section{Assessing the Impact of University-Firm Collaboration on Innovation-related Financial Performance}

\section{Acknowledgements}

- Data Gathering: The dataset of the Spanish Panel of Technological Innovation (PITEC) have been provided by the Spanish Foundation for Science and Technology (FECYT) and the National Institute of Statistics (INE) from which other information about the Spanish chemicals industry was also retrieved.

- PhD Funding: The authors are a PhD fellow and a supervisor of RUNIN project, a European Training Network for Early-Stage Researchers, funded by EU's Horizon 2020 research and innovation programme under Marie Skłodowska-Curie grant agreement \# 722295.

\section{References}

Abreu, M, \& Grinevich, V. (2013). The nature of academic entrepreneurship in the UK: Widening the focus on entrepreneurial activities. Research Policy, 42(2), 408-422. DOI: https://doi.org/10.1016/j.respol.2012.10.005

Bogetoft P., \& Otto, L. (2011). Benchmarking with DEA, SFA, and R. New York, USA: Springer-Verlag. International Series in Operations Research \& Management Science. DOI: https://doi.org/10.1007/978-1-4419-7961-2

BBVA-IVIE Foundation. (2009). Spanish Productive Capital. Capital and Growth Resource Notes, September 2019. Retrieved from: https://www.fbbva.es/en/publicaciones/elcapital-productivo-espanol-2/

Carayannis, E., \& Campbell, D. (2009). 'Mode 3' and 'Quadruple Helix': Toward a $21^{\text {st }}$ Century Fractal Innovation Ecosystem. International Journal of Technology Management, 46(3/4). DOI: https://doi.org/10.1504/IJTM.2009.023374

Charnes, A., Cooper, W. W., \& Rhodes, E. (1978). Measuring the efficiency of decision making units. European Journal of Operational Research, 2(6), 429-444. DOI: https://doi.org/10.1016/0377-2217(78)90138-8

Chesbrough, H. W. (2006). Open Business Models: How to Thrive in the New Innovation Landscape. Boston, USA: Harvard Business School Press. Retrieved from: https://hbr.org/product/open-business-models-how-to-thrive-in-the-newinnovation-landscape/4273-HBK-ENG

Cohen, W. M., \& Levinthal, D. A. (1990). Absorptive Capacity: A New Perspective on Learning and Innovation. Administrative Science Quarterly, 35(1), 128-152. DOI: https://doi.org/10.2307/2393553

Cooke, P., Uranga, M. G., \& Etxebarria, G. (1997). Regional innovation systems: Institutional and organizational dimensions. Research Policy, 26(4-5), 475-491. DOI: https://doi.org/10.1016/S0048-7333(97)00025-5 


\section{Assessing the Impact of University-Firm Collaboration on Innovation-related Financial Performance}

D'Este, P., \& Patel, P. (2007). University-industry linkages in the UK: What are the factors underlying the variety of interactions with industry? Research Policy, 36(9), 1295-1313. DOI: https://doi.org/10.1016/j.respol.2007.05.002

Hoaglin, D. C., Iglewicz, B., \& Tukey J.W. (1986). Performance of Some Resistant Rules for Outlier Labelling. Journal of the American Statistical Association, 81(396), 991-999. Retrieved from: https://www.jstor.org/stable/2289073

Etzkowitz, H., \& Leydesdorff, L. (1997). Universities and the Global Knowledge Economy: A Triple Helix of University-Industry-Government Relations. London, UK: Pinter. Retrieved from: https://www.bloomsbury.com/us/universities-and-the-global-knowledgeeconomy-9780826479068

Freeman, R. E. (1984). Strategic Management: A Stakeholder Approach. Boston, USA: Pitman Publishing. DOI: https://doi.org/10.1017/CBO9781139192675

Friedman, M. (1970). The Social Responsibility of Business Is to Increase Its Profits. The New York Times Magazine. September 13, 32-33, 122-124. DOI: https://doi.org/10.1007/978-3-540-70818-6_14

Göransson, B., \& Brundenius, C. (2011). Universities in Transition: The Changing Role and Challenges for Academic Institutions. Ottawa, Canada: Springer. DOI: https://doi.org/10.1007/978-1-4419-7509-6

Grifell-Tatjé, E., \& Lovell, C. A. K. (2015). Productivity Accounting: The Economics of Business Performance. New York, USA: Cambridge University Press. DOI: https://doi.org/10.1017/CBO9781139021418

Grifell-Tatjé, E., \& Lovell, C. A. K. (2016). Exact Relationship between Fisher Indexes and Theoretical Indexes. In Aparicio, J., Lovell, C.A.K., \& Pastor, J.T. (Eds.). Advances in Efficiency and Productivity. Berlin: Springer. DOI: https://doi.org/10.1007/978-3-31948461-7_5

Griffin, A. (1997). PDMA Research on New Product Development Practices: Updating Trends and Benchmarking Best Practices. Journal of Product Innovation Management, 14, 429-458. DOI: https://doi.org/10.1111/1540-5885.1460429

Grossman, G. M., \& Helpman, E. Trade, Knowledge Spillovers and Growth. European Economic Review, 35(2-3), 517-526. DOI: https://doi.org/10.1016/00142921(91)90153-A

Hoaglin, D. C., Iglewicz, B., \& Tukey, J. W. (1986). Performance of Some Resistant Rules for Outlier Labelling. Journal of the American Statistical Association, 81(396), 991-999. DOI: https://doi.org/10.1080/01621459.1986.10478363

Hughes, A., \& Kitson, M. (2012). Pathways to Impact and the Strategic Role of Universities: New Evidence on the Breadth and Depth of University Knowledge Exchange in the UK and the Factors Constraining its Development. Cambridge Journal of Economics, 36(3), 723-750. DOI: https://doi.org/10.1093/cje/bes017 


\section{Assessing the Impact of University-Firm Collaboration on Innovation-related Financial Performance}

Laursen, K., \& Salter, A. (2006). Open for Innovation: The Role of Openness in Explaining Innovation Performance among UK Manufacturing Firms. Strategic Management Journal, 27(2), 131-150. DOI: https://doi.org/10.1002/smj.507

Lovell, C. A. K. (2003). The Decomposition of Malmquist Productivity Indexes. Journal of Productivity Analysis, 20(3), 437-458. DOI: https://doi.org/10.1023/A:1027312102834

Lundvall, B. Å. (1992). National Systems of Innovation: Towards a Theory of Innovation and Interactive Learning. London, UK: Pinter Publishers. Retrieved from: https://www.jstor.org/stable/j.ctt1gxp7cs

Manrique, S. (2018). Personal Networks and Trust in Public-Private R\&D Partnerships: A Case Study from Spain. RUNIN Project Working Paper Series, 2018(2), 1-31. DOI: https://doi.org/10.3990/4.2535-5686.2018.12

Mascarenhas, C., Ferreira, J. J., \& Marques, C. (2018). University-Industry Cooperation: A Systematic Literature Review and Research Agenda. Science and Public Policy, 45(5), 708-718. DOI: https://doi.org/10.1093/scipol/scy003

Nelson, R. R. (1993). National Innovation Systems: A Comparative Analysis. Oxford, UK: Oxford University Press. Retrieved from: https://global.oup.com/academic/product/national-innovation-systems9780195076172

Perkmann, M., \& Walsh, K. (2007). University-Industry Relationships and Open Innovation: Towards a Research Agenda. International Journal of Management Reviews, 9(4), 259280. DOI: https://doi.org/10.1111/j.1468-2370.2007.00225.x

Perkmann, M., Tartari, V., McKelvey, M., Autio, E., Broström, A., D’Este, P., Fini, R., Geuna, A., Grimaldi, R., Hughes, A., Krabel, S., Kitson, M., Llerena, P., Lissoni, F., Salter, A., \& Sobrero, M. (2013). Academic Engagement and Commercialisation: A Review of the Literature on University-Industry Relations. Research Policy, 42(2), 423-442. DOI: https://doi.org/10.1016/j.respol.2012.09.007

Santoro, M. D., \& Chakrabarti, A. K. (2002). Firm Size and Technology Centrality in IndustryUniversity Interactions. Research Policy, 31(7), 1163-1180. DOI: https://doi.org/10.1016/S0048-7333(01)00190-1

Shephard, R. W. (1970). Theory of Cost and Production Functions. Princeton, USA: Princeton University Press. Retrieved from: https://press.princeton.edu/books/ebook/9781400871087/theory-of-cost-andproduction-functions

Soh, P. H., \& Subramanian A. M. (2014). When Do Firms Benefit from University-Industry R\&D Collaborations? The Implications of Firm R\&D Focus on Scientific Research and Technological Recombination. Journal of Business Venturing, 29(6), 807-821. DOI: https://doi.org/10.1016/j.jbusvent.2013.11.001 


\section{Assessing the Impact of University-Firm Collaboration on Innovation-related Financial Performance}

Valmaseda-Andia, O., Albizu-Gallastegi, E., Fernández-Esquinas, M., \& Fernández-deLucio, I. (2015). La Relación entre las Empresas Españolas y el CSIC: Motivaciones, Mecanismos y Beneficios desde la Perspectiva Empresarial. Revista Española de Documentación Científica, 38(4), e109. DOI: https://doi.org/10.3989/redc.2015.4.1263

Van Loggerenberg, B. J., \& Cucchiaro, S. J. (1981). Productivity Measurement and the Bottom Line. National Productivity Review. Winter 1981-82, 87-99. DOI: https://doi.org/10.1002/npr.4040010111

Winston, A. (2019). Is the Business Roundtable Statement Just Empty Rhetoric? Harvard Business Review, August 30. Retrieved from: https://hbr.org/2019/08/is-the-businessroundtable-statement-just-empty-rhetoric 